2014

\title{
Documentation of Ancestral Caddo Ceramic Vessels in the Smith County Historical Museum Collections
}

Timothy K. Perttula

Heritage Research Center, Stephen F. Austin State University

Bo Nelson

Robert Z. Selden Jr.

Heritage Research Center, Stephen F. Austin State University

Mark Walters

Follow this and additional works at: https://scholarworks.sfasu.edu/ita

Part of the American Material Culture Commons, Archaeological Anthropology Commons, Environmental Studies Commons, Other American Studies Commons, Other Arts and Humanities Commons, Other History of Art, Architecture, and Archaeology Commons, and the United States History Commons

Tell us how this article helped you.

This Article is brought to you for free and open access by the Center for Regional Heritage Research at SFA ScholarWorks. It has been accepted for inclusion in Index of Texas Archaeology: Open Access Gray Literature from the Lone Star State by an authorized editor of SFA ScholarWorks. For more information, please contact cdsscholarworks@sfasu.edu. 


\section{Documentation of Ancestral Caddo Ceramic Vessels in the Smith County Historical Museum Collections}

\section{Creative Commons License}

\section{(c) (1) \&}

This work is licensed under a Creative Commons Attribution-NonCommercial 4.0 International License 


\section{Documentation of Ancestral Caddo Ceramic Vessels in the Smith County Historical Museum Collections}

Timothy K. Perttula, Bo Nelson, Robert Z. Selden Jr., and Mark Walters

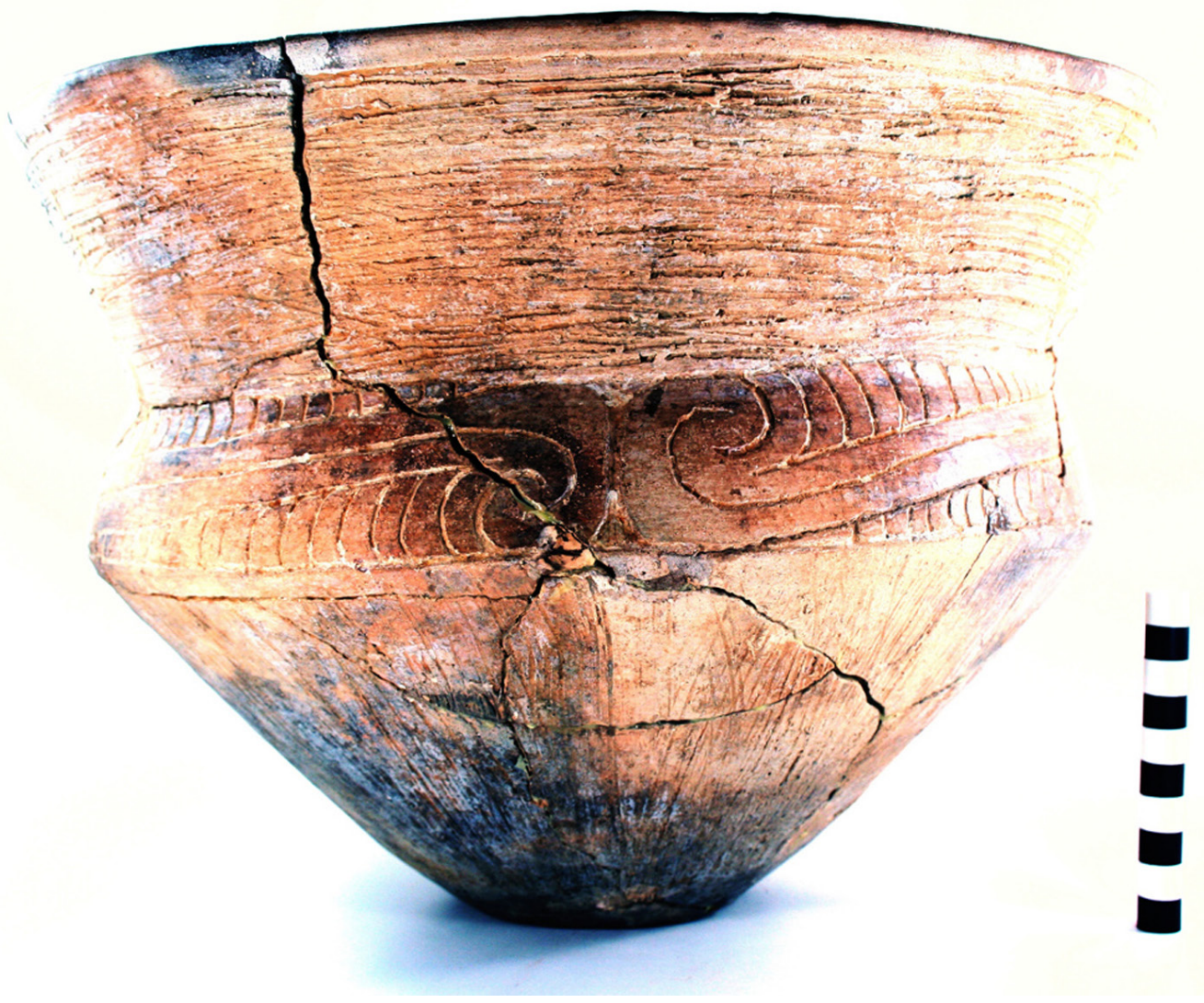

Special Publication No. 35

Friends of Northeast Texas Archaeology (Austin and Pittsburg) 
Distribution, Bo Nelson, 344 CR 4154

Pittsburg, Texas 75686

RBoNelson@aol.com

\section{Cover art:}

Figure 1 (Engraved-brushed compound bowl, Arms Creek)

Copyright (C) 2014, Friends of Northeast Texas Archaeology (Austin and Pittsburg) 


\section{Table of Contents}

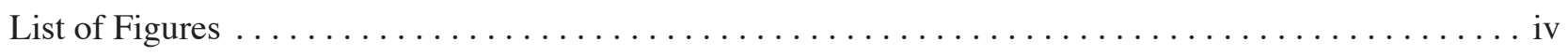

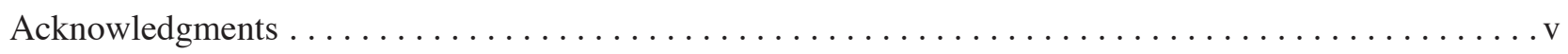

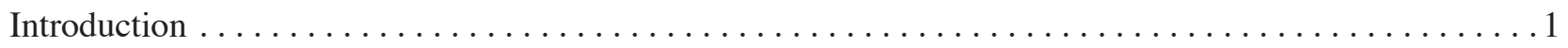

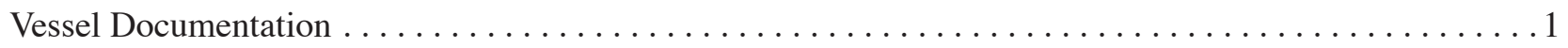

Lake $\mathrm{O}^{\prime}$ the Pines Vessels, Marion and Upshur Counties, Texas $\ldots \ldots \ldots \ldots \ldots \ldots \ldots$

Vessels from Smith County Sites . . . . . . . . . . . . . . 26

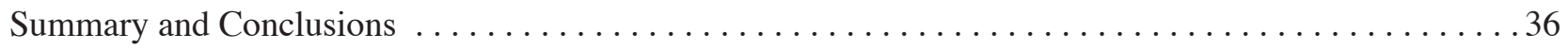

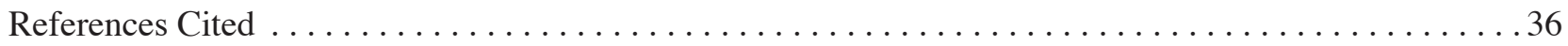




\section{List of Figures}

Figure 1. Large cf. Taylor Engraved compound bowl in the SCHM collections. . . . . . . . . . . 2

Figure 2. Ripley Engraved, var. McKinney carinated bowl $\ldots \ldots \ldots \ldots \ldots \ldots \ldots \ldots \ldots \ldots \ldots$

Figure 3. Simms Engraved deep bowl: a, side view; b, view of decorated rim . . . . . . . . . . . . 4

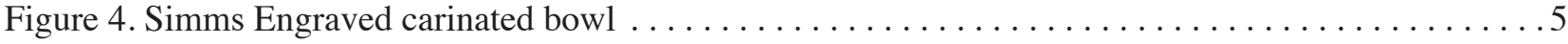

Figure 5. Simms Engraved carinated bowl: a, side view; b, close-up view of the engraved rim panel . . . 6

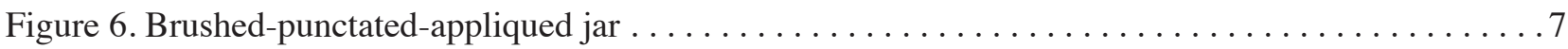

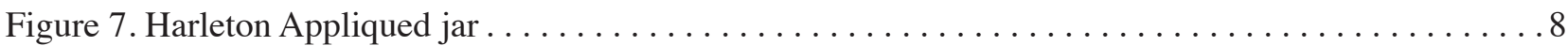

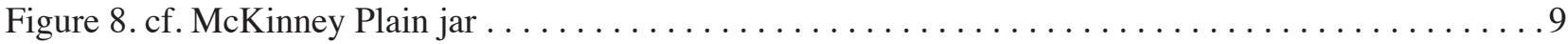

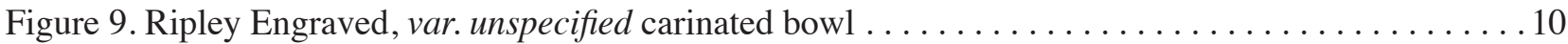

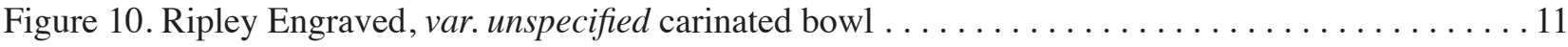

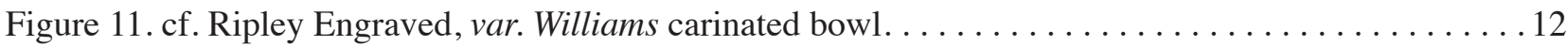

Figure 12. cf. Ripley Engraved, var. McKinney carinated bowl: a, central triangle element;

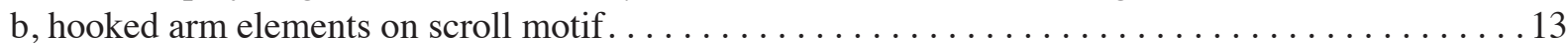

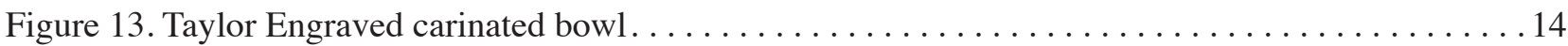

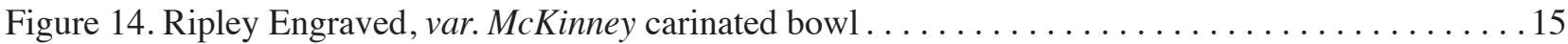

Figure 15. Conjoined cf. Simms Engraved-Taylor Engraved vessel . . . . . . . . . . . . . . . . . 16

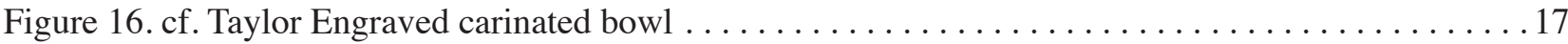

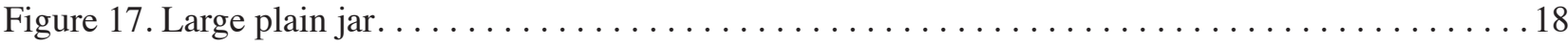

Figure 18. Taylor Engraved carinated bowl from the Southall site (41UR3) . . . . . . . . . . . . . 19

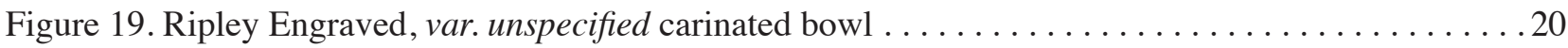

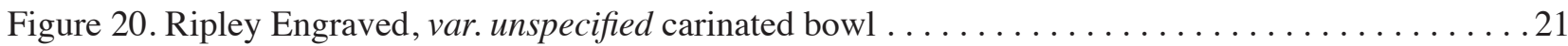

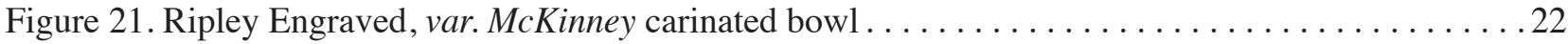

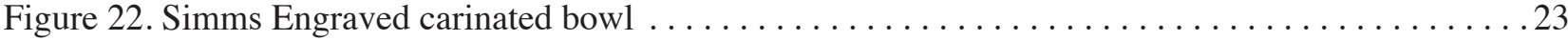

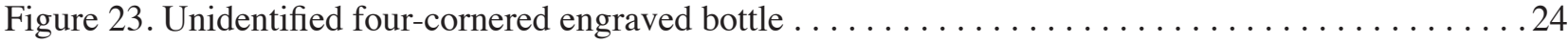

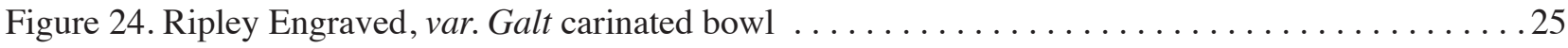

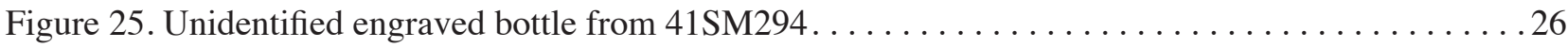

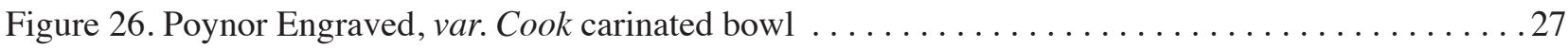

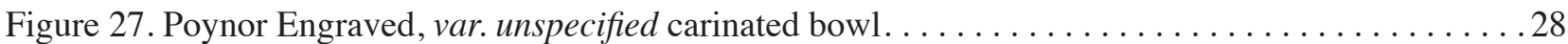

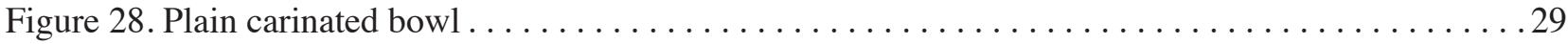

Figure 29. Bullard Brushed jar. .................................... 30

Figure 30. Plain bowl: a, side view; $b$, view of interior thickened $\operatorname{rim} \ldots \ldots \ldots \ldots \ldots \ldots \ldots \ldots \ldots$

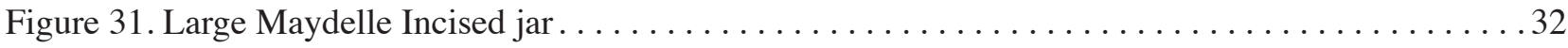

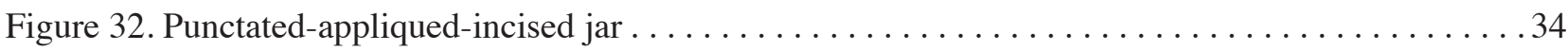

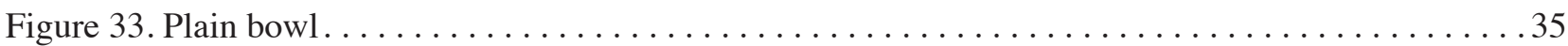


Documentation of Ancestral Caddo Ceramic Vessels in the Smith County Historical Museum Collections

\section{Acknowledgments}

We thank Carol Kehl, Melanie Leath, Virginia Leath, and Iris Mayer for their help in documenting the ancestral Caddo ceramic vessels in the Smith County Historical Museum collections. 



\section{Introduction}

This report puts on record the collection of 34 ancestral Caddo vessels held by the Smith County Historical Museum (SCHM) in Tyler, Texas. Most of the collection was donated to the SCHM in 2013, but several were also donated in 1985 (Carol Kehl, April 2014 personal communication).

The vessels in this collection have been documented following the methods employed by the Friends of Northeast Texas Archaeology and Archeological \& Environmental Consultants, LLC on a number of ancestral Caddo ceramic collections from East Texas archaeological sites (e.g., Perttula 2011, 2013, 2014; Perttula and Nelson 2013; Perttula and Thacker 2014; Perttula et al. 2007, 2009a, 2009b, 2010a, 2010b, 2010c, 2012a, 2012b, 2012c, 2013, 2014). The provenance of the Caddo vessels includes a number of vessels from sites at Lake O' the Pines in the Big Cypress Creek basin, while the other 10 vessels are believed to have been collected from sites in the upper Neches River basin in Smith County, Texas. We discuss these conclusions in the "Summary and Conclusions" section of the report, relying on the decorative styles and types of the vessels (see Suhm and Jelks 1962) to sort them into the material culture remains known to be associated with different ancestral Caddo cultural groups in East Texas.

\section{Vessel Documentation}

\section{Lake O' the Pines Vessels, Marion and Upshur Counties, Texas}

Twenty-four of the Caddo ceramic vessels in the SCHM collection are from sites at Lake O' the Pines on Big Cypress Creek in Marion and Upshur counties, Texas; they were collected in 1985. This part of East Texas is well known as the locus of a number of important post-A.D. 1430 Caddo sites and cemeteries (Perttula 2012:Figure 13-2 and Table 13-3).

The majority of these vessels $(n=17)$ are from at least two cemeteries along Arms Creek (in both Marion and Upshur counties, according to the available provenience information written on the vessels, although the Arms Creek drainage is situated in Harrison and Marion counties). There are two large ancestral Caddo community cemeteries known in the Arms Creek drainage - the Pea Patch or Patton (41HS825) and H. R. Taylor (41HS3) sites - as well as 41HS1 (see Thurmond 1990), but the SCHM sites must be farther downstream since they are reported to be in Marion County; the Upshur County ceramic vessels would be from a site in another drainage at Lake O' the Pines. Marion County sites in this area known to have Caddo archaeological deposits include 41MR5, 41MR6, and 41MR10 (see Thurmond 1990).

The M. C. site is the Southall site (41UR3); there are five vessels from this site in the SCHM collection. This is a large community cemetery, with more than 200+ interments, on Meddlin Creek in the Lake O' the Pines area (Perttula 2012:Table 13-3). One possible Early Caddo (dating before ca. A.D. 12001300) vessel in the collection is from a site labeled the Pine Bluff site; its location in the Lake O' the Pines area in Upshur County is unknown. 
SITE NAME OR SITE NUMBER: Arms Creek

VESSEL NO.: 3-20-85

VESSEL FORM: Compound bowl

NON-PLASTICS AND PASTE: grog

RIM AND LIP FORM: Everted rim and rounded lip

CORE COLOR: F (fired in a reducing environment and cooled in the open air)

INTERIOR SURFACE COLOR: yellowish-brown; fire clouds on the body and base

EXTERIOR SURFACE COLOR: yellowish-

brown; fire clouds on the rim, body, and base

WALL THICKNESS (IN MM): rim, 6.0 mm

INTERIOR SURFACE TREATMENT: smoothed

EXTERIOR SURFACE TREATMENT: burnished on the lower rim panel

HEIGHT (IN CM): 24.2

ORIFICE DIAMETER (IN CM): 34.7

DIAMETER AT BOTTOM OF RIM OR NECK (IN CM): 29.4

BASE DIAMETER (IN CM) AND SHAPE OF

BASE: 9.3; circular and flat

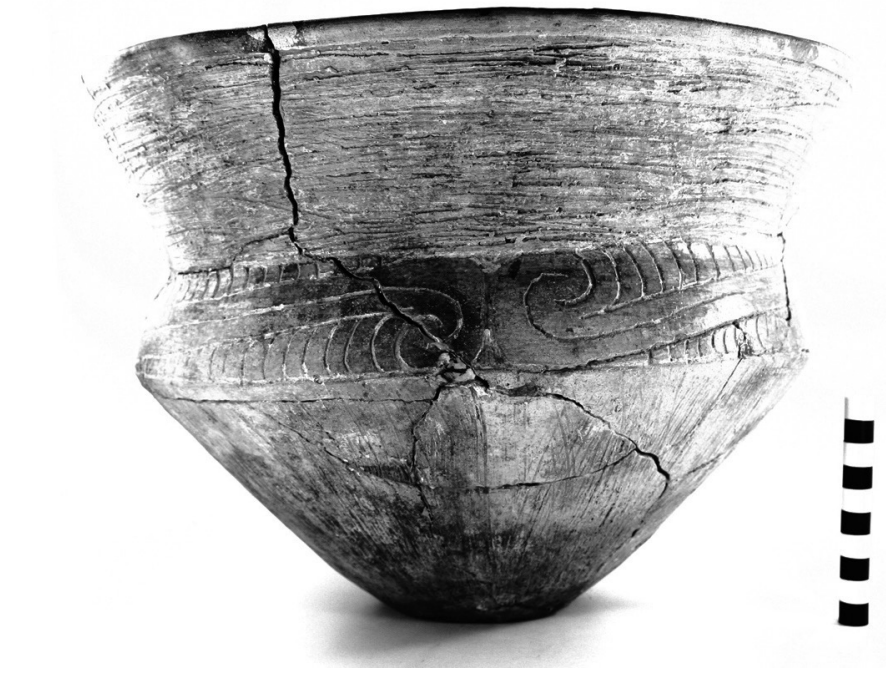

Figure 1. Large cf. Taylor Engraved compound bowl in the SCHM collections.

ESTIMATED VOLUME (IN LITERS): 6.7

DECORATION (INCLUDING MOTIF AND ELEMENTS WHEN APPARENT): The upper rim panel has horizontal brushing marks, while the vessel body has vertical brushing marks. The lower rim panel has an engraved scroll motif repeated four times around the vessel; the scroll motifs end in hooked arm elements. The upper and lower scroll fill elements are filled with near vertical engraved lines. There are excised brackets that divide the engraved scrolls (Figure 1).

PIGMENT USE AND LOCATION ON VESSEL: white pigment in engraved lines

TYPE AND VARIETY (IF KNOWN): cf. Taylor Engraved 
SITE NAME OR SITE NUMBER: Arms Creek

VESSEL NO.: 4-2-85

VESSEL FORM: Carinated bowl

NON-PLASTICS AND PASTE: grog

RIM AND LIP FORM: Direct rim and a rounded lip

CORE COLOR: B (fired and cooled in a reducing environment)

INTERIOR SURFACE COLOR: grayish-brown

EXTERIOR SURFACE COLOR: grayish-brown; fire clouds on the base

WALL THICKNESS (IN MM): rim, 6.4 mm

INTERIOR SURFACE TREATMENT: smoothed

EXTERIOR SURFACE TREATMENT: burnished

HEIGHT (IN CM): 8.0

ORIFICE DIAMETER (IN CM): 15.0

DIAMETER AT BOTTOM OF RIM OR NECK

(IN CM): 14.0

BASE DIAMETER (IN CM) AND SHAPE OF

BASE: 6.0; circular and flat

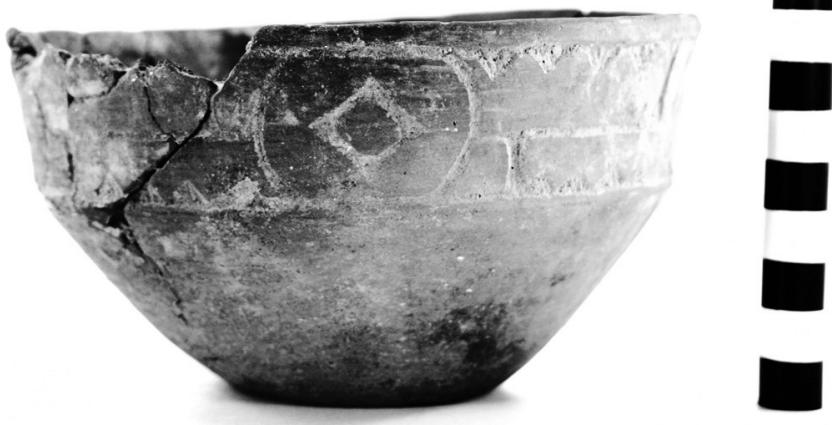

Figure 2. Ripley Engraved, var. McKinney carinated bowl.

ESTIMATED VOLUME (IN LITERS): 0.7

DECORATION (INCLUDING MOTIF AND ELEMENTS WHEN APPARENT): The rim panel has engraved circular central elements repeated four times around the vessel. Within the central circles are single negative ovals and excised rays. Between the central circles is a horizontal scroll line connected to the rim and carination by excised brackets. Above and below the horizontal scrolls are a series of excised pendant triangles (Figure 2).

PIGMENT USE AND LOCATION ON VESSEL: none

TYPE AND VARIETY (IF KNOWN): Ripley Engraved, var. McKinney 
SITE NAME OR SITE NUMBER: Arms Creek (Upshur County)

VESSEL NO.: 4-5-85

VESSEL FORM: Deep bowl (Figure 3a)

NON-PLASTICS AND PASTE: grog

RIM AND LIP FORM: Inverted rim and a flat and notched lip

CORE COLOR: A (fired and cooled in an oxidizing environment)

INTERIOR SURFACE COLOR: dark red

EXTERIOR SURFACE COLOR: dark red

WALL THICKNESS (IN MM): rim, $4.8 \mathrm{~mm}$

INTERIOR SURFACE TREATMENT: smoothed

EXTERIOR SURFACE TREATMENT: burnished

HEIGHT (IN CM): 21.4

ORIFICE DIAMETER (IN CM): 20.6

DIAMETER AT BOTTOM OF RIM OR NECK (IN CM): 23.2

BASE DIAMETER (IN CM) AND SHAPE OF BASE: 10.7; circular and flat

ESTIMATED VOLUME (IN LITERS): 3.4

DECORATION (INCLUDING MOTIF AND ELEMENTS WHEN APPARENT): The vessel has a red slip on both interior and exterior surfaces. On the rim are a series of sets of short curvilinear engraved lines oriented in opposing directions. These curvilinear lines are divided by two sets of closely-spaced curvilinear lines oriented in opposing directions (Figure 3b).

PIGMENT USE AND LOCATION ON VESSEL: none TYPE AND VARIETY (IF KNOWN): Simms Engraved

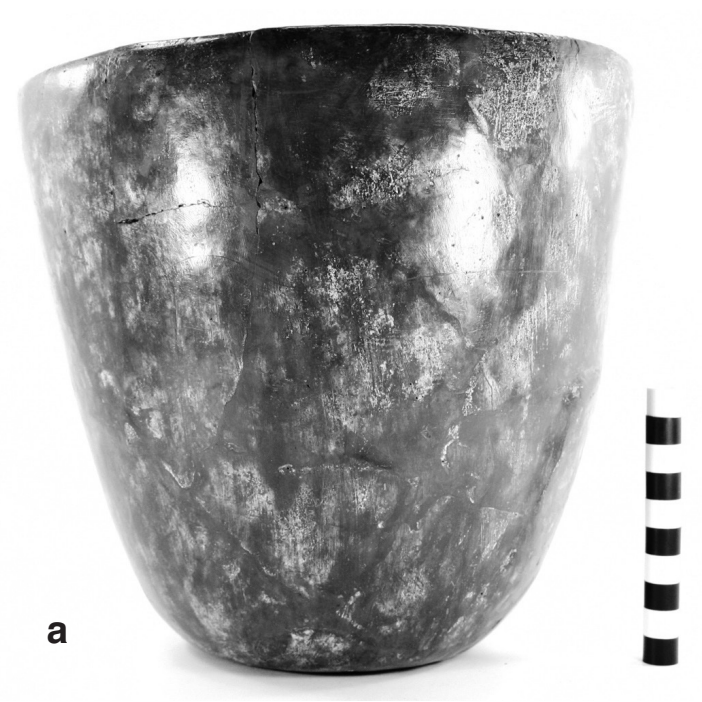

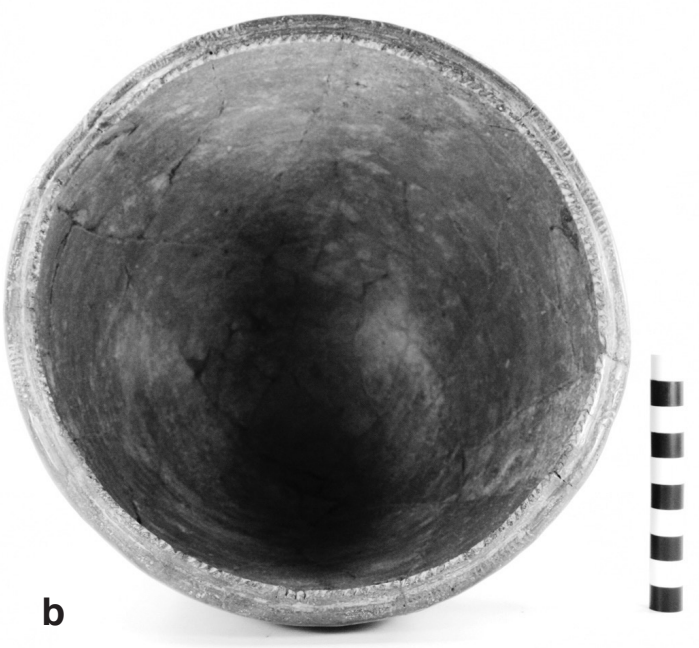

Figure 3. Simms Engraved deep bowl: a, side view; $b$, view of decorated rim. 
SITE NAME OR SITE NUMBER: Arms Creek

VESSEL NO.: 3-30-85

VESSEL FORM: Carinated bowl

NON-PLASTICS AND PASTE: grog

RIM AND LIP FORM: Inverted rim and rounded lip

CORE COLOR: A (fired and cooled in an oxidizing environment)

INTERIOR SURFACE COLOR: brown

EXTERIOR SURFACE COLOR: reddish-brown

WALL THICKNESS (IN MM): $\operatorname{rim}, 5.8 \mathrm{~mm}$

INTERIOR SURFACE TREATMENT: smoothed

EXTERIOR SURFACE TREATMENT:

smoothed

HEIGHT (IN CM): 16.0

ORIFICE DIAMETER (IN CM): 25.0

DIAMETER AT BOTTOM OF RIM OR NECK

(IN CM): 28.3

BASE DIAMETER (IN CM) AND SHAPE OF

BASE: 8.5; circular and rounded

ESTIMATED VOLUME (IN LITERS): 3.6

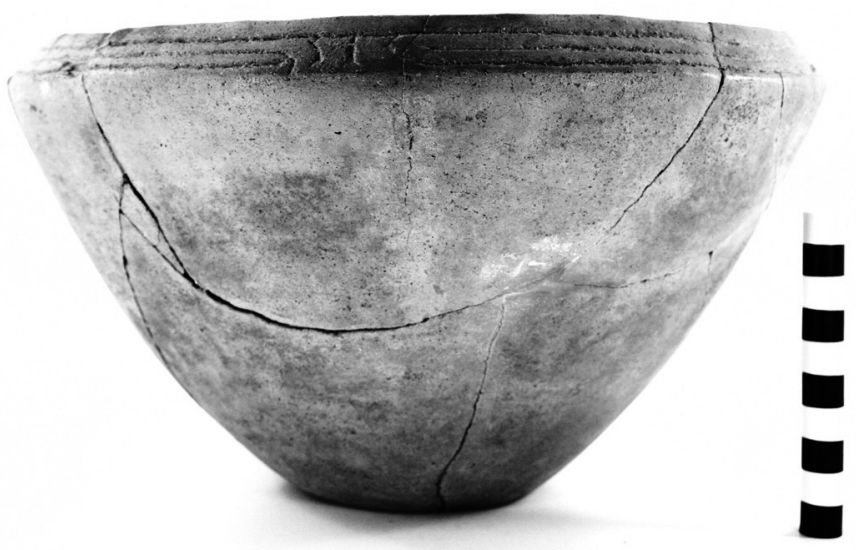

Figure 4. Simms Engraved carinated bowl.

DECORATION (INCLUDING MOTIF AND ELEMENTS WHEN APPARENT): The distinctive short rim panel has a series of three upper and lower horizontal scroll lines that are divided by cross-hatched brackets (Figure 4).

PIGMENT USE AND LOCATION ON VESSEL: none

TYPE AND VARIETY (IF KNOWN): Simms Engraved 
SITE NAME OR SITE NUMBER: Arms Creek

VESSEL NO.: 3-16-85

VESSEL FORM: Carinated bowl

NON-PLASTICS AND PASTE: grog

RIM AND LIP FORM: Inverted rim and rounded $\operatorname{lip}$

CORE COLOR: $\mathrm{G}$ (fired in a reducing environment and cooled in the open air)

INTERIOR SURFACE COLOR: black

EXTERIOR SURFACE COLOR: yellowishbrown; fire clouds on the rim, body, and base

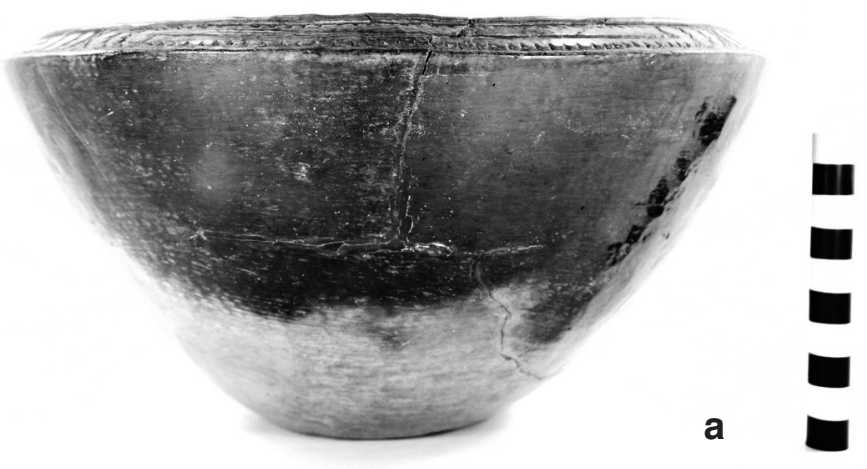

WALL THICKNESS (IN MM): rim, $6.0 \mathrm{~mm}$

INTERIOR SURFACE TREATMENT: burnished

EXTERIOR SURFACE TREATMENT: burnished

HEIGHT (IN CM): 13.3

ORIFICE DIAMETER (IN CM): 23.6

DIAMETER AT BOTTOM OF RIM OR NECK (IN CM): 26.5

BASE DIAMETER (IN CM) AND SHAPE OF BASE: 8.5; circular and flat

ESTIMATED VOLUME (IN LITERS): 2.8

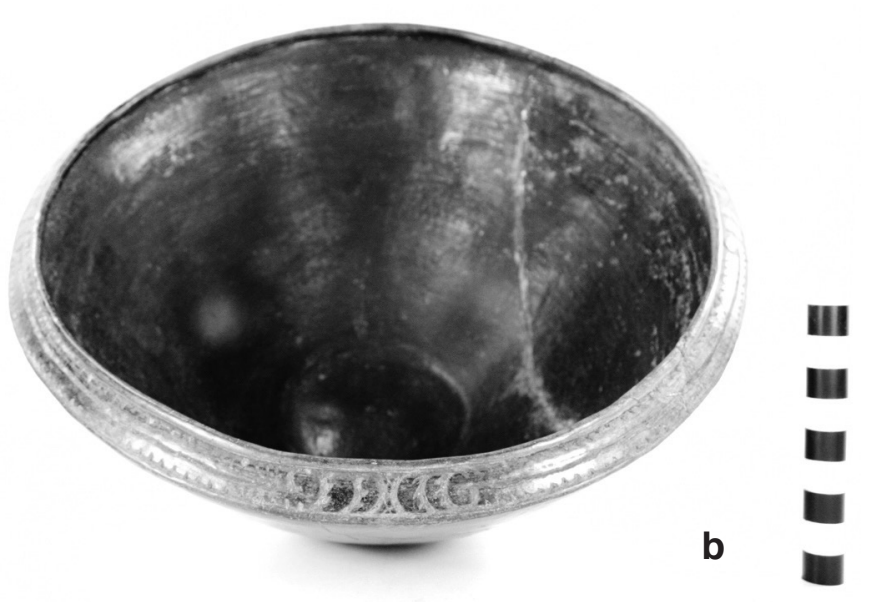

Figure 5. Simms Engraved carinated bowl: a, side view; $b$, close-up view of the engraved rim panel.

DECORATION (INCLUDING MOTIF AND ELEMENTS WHEN APPARENT): The rim panel has a horizontal scroll motif repeated four times around the vessel. Above and below the scroll lines are small excised pendant triangles (Figure 5a). The scroll motifs are divided by engraved brackets (with tick marks) and two sets of curvilinear engraved lines with tick marks pointing towards the brackets (Figure 5b).

PIGMENT USE AND LOCATION ON VESSEL: red in the engraved lines

TYPE AND VARIETY (IF KNOWN): Simms Engraved 
SITE NAME OR SITE NUMBER: Arms Creek (Upshur County)

VESSEL NO.: 4-18-85

VESSEL FORM: Jar

NON-PLASTICS AND PASTE: bone and hematite

RIM AND LIP FORM: Everted rim and a rounded lip

CORE COLOR: F (fired in a reducing environment and cooled in the open air)

INTERIOR SURFACE COLOR: reddish-brown; fire clouds on the rim, body, and base

EXTERIOR SURFACE COLOR: reddish-brown; fire clouds on the base

WALL THICKNESS (IN MM): $\operatorname{rim}, 6.0 \mathrm{~mm}$

INTERIOR SURFACE TREATMENT: smoothed

EXTERIOR SURFACE TREATMENT: none

HEIGHT (IN CM): 17.7

ORIFICE DIAMETER (IN CM): 15.7

DIAMETER AT BOTTOM OF RIM OR NECK

(IN CM): 15.2

BASE DIAMETER (IN CM) AND SHAPE OF BASE: 7.0; circular and flat

ESTIMATED VOLUME (IN LITERS): 2.5

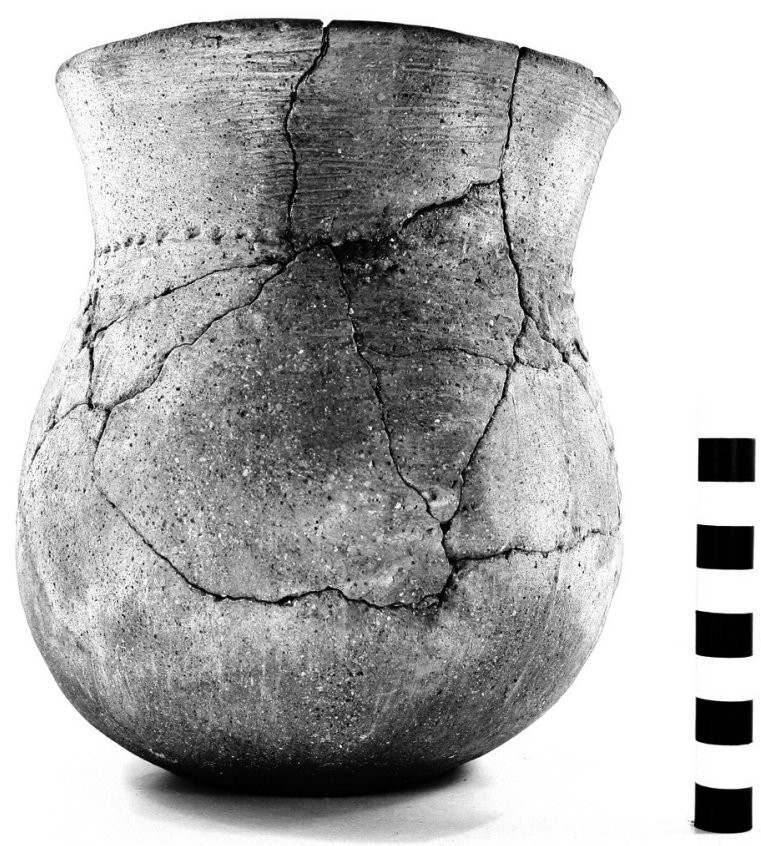

Figure 6. Brushed-punctated-appliqued jar.

DECORATION (INCLUDING MOTIF AND ELEMENTS WHEN APPARENT): The rim has horizontal brushing marks and a row of tool punctates at the rim-body juncture. The vessel body has four appliqued ridge triangles pendant from the rim-body juncture; these triangles are filled with a series of horizontal appliqued ridges. The appliqued ridge triangles are divided by vertical appliqued ridges. Between the appliqued ridges and appliqued triangles the vessel body has vertical brushing marks that extend from the rim-body juncture to near the base (Figure 6).

PIGMENT USE AND LOCATION ON VESSEL: none

TYPE AND VARIETY (IF KNOWN): Unidentified utility ware 
SITE NAME OR SITE NUMBER: Arms Creek

VESSEL NO.: 3-30-85

VESSEL FORM: Jar with four rim peaks

NON-PLASTICS AND PASTE: grog and hematite

RIM AND LIP FORM: Direct rim and rounded lip

CORE COLOR: G (fired in a reducing environment and cooled in the open air)

INTERIOR SURFACE COLOR: very dark grayish-brown; organic residue on the rim and body

EXTERIOR SURFACE COLOR: yellowishbrown; fire clouds on the rim, body, and base; organic residue on the rim and body

WALL THICKNESS (IN MM): rim, 6.7 mm

INTERIOR SURFACE TREATMENT: smoothed

EXTERIOR SURFACE TREATMENT: none

HEIGHT (IN CM): 15.5

ORIFICE DIAMETER (IN CM): 14.7

DIAMETER AT BOTTOM OF RIM OR NECK (IN CM): 14.7

BASE DIAMETER (IN CM) AND SHAPE OF

BASE: 8.0; circular and flat

ESTIMATED VOLUME (IN LITERS): 1.4

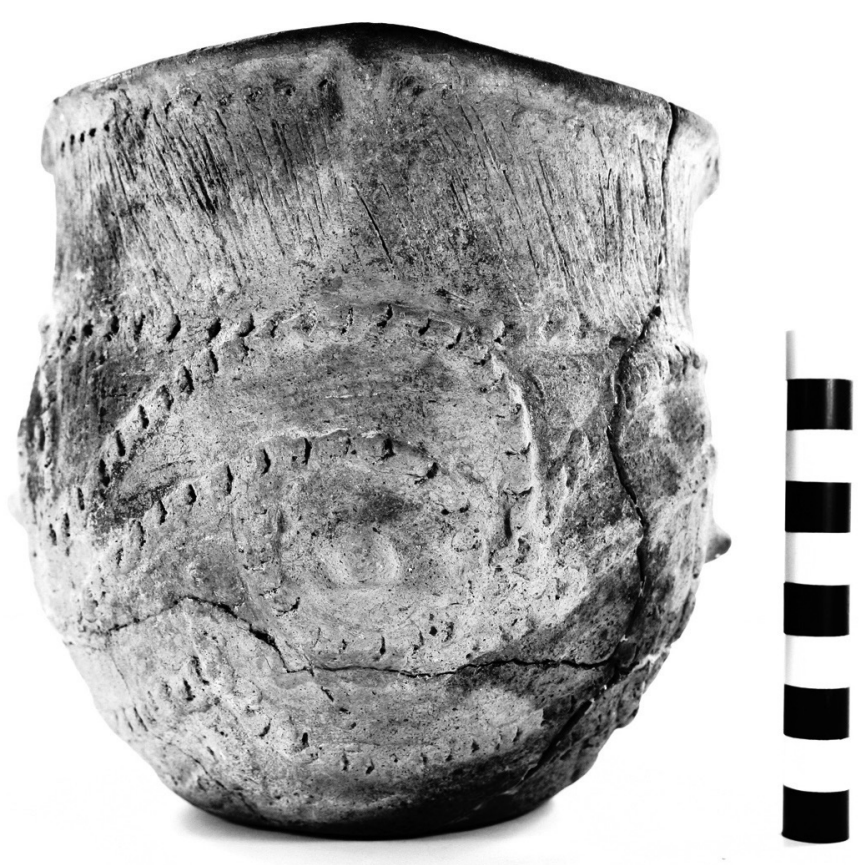

Figure 7. Harleton Appliqued jar.

DECORATION (INCLUDING MOTIF AND ELEMENTS WHEN APPARENT): The vessel rim has vertical brushing marks as well as tool punctated rows under the lip and at the rim-body juncture. There are also appliqued lugs under each rim peak. The vessel body has an appliqued fillet scroll and circle motif repeated four times around the vessel. Each central circle has a small appliqued node at its center; the appliqued circles are aligned on the vessel body under the rim peaks (Figure 7).

PIGMENT USE AND LOCATION ON VESSEL: none

TYPE AND VARIETY (IF KNOWN): Harleton Appliqued 
SITE NAME OR SITE NUMBER: Arms Creek

VESSEL NO.: 3-30-85

VESSEL FORM: Jar

NON-PLASTICS AND PASTE: bone and grog

RIM AND LIP FORM: Everted rim and rounded lip

CORE COLOR: $\mathrm{F}$ (fired in a reducing environment and cooled in the open air)

INTERIOR SURFACE COLOR: yellowish-brown; fire clouds on the rim, body, and base

EXTERIOR SURFACE COLOR: yellowishbrown; fire clouds on the rim, body, and base; organic residue on the body

WALL THICKNESS (IN MM): rim, $6.5 \mathrm{~mm}$

INTERIOR SURFACE TREATMENT:

smoothed

EXTERIOR SURFACE TREATMENT: none

HEIGHT (IN CM): 31.6

ORIFICE DIAMETER (IN CM): 34.7

DIAMETER AT BOTTOM OF RIM OR NECK (IN CM): 28.6

BASE DIAMETER (IN CM) AND SHAPE

OF BASE: 11.4; circular and flat

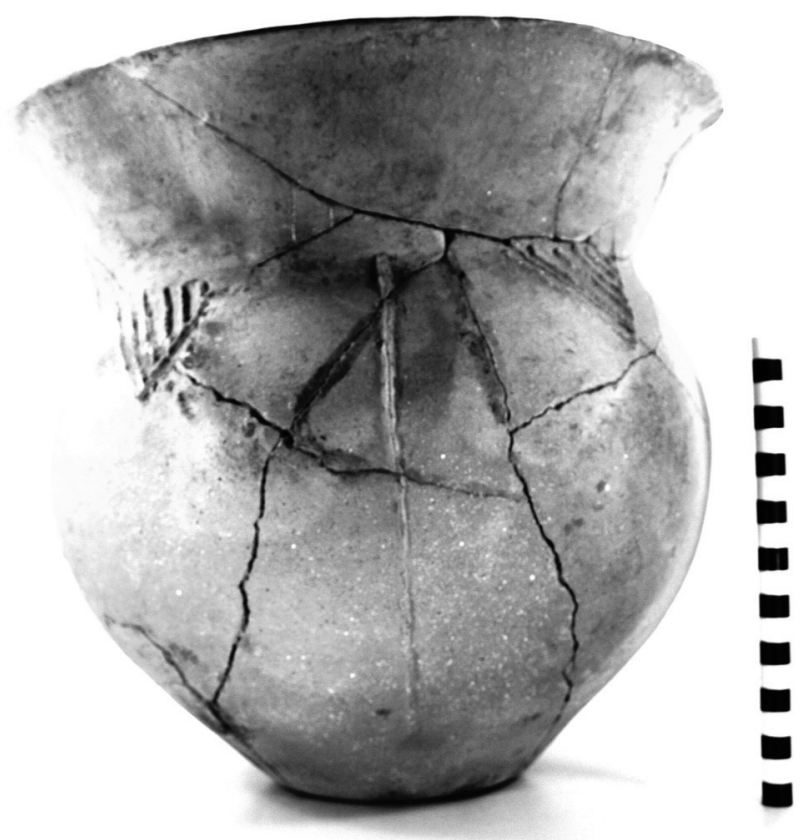

Figure 8. cf. McKinney Plain jar.

ESTIMATED VOLUME (IN LITERS): 14.3

DECORATION (INCLUDING MOTIF AND ELEMENTS WHEN APPARENT): The rim of the vessel is plain. The vessel body has four sets of appliqued ridge triangles pendant from the rim-body juncture. These appliqued triangles have a series of short diagonal appliqued ridges. The appliqued triangle elements are divided by four vertical appliqued ridges that extend from the rim-body juncture to near the vessel base (Figure 8).

PIGMENT USE AND LOCATION ON VESSEL: none

TYPE AND VARIETY (IF KNOWN): cf. McKinney Plain 
SITE NAME OR SITE NUMBER: Arms Creek

VESSEL NO.: 3-21-85

VESSEL FORM: Carinated bowl

NON-PLASTICS AND PASTE: grog

RIM AND LIP FORM: Direct rim and rounded, exterior folded lip

CORE COLOR: $\mathrm{G}$ (fired in a reducing environment and cooled in the open air)

INTERIOR SURFACE COLOR: brown; fire clouds on the rim, body, and base

EXTERIOR SURFACE COLOR: grayish-brown; fire clouds on the base; organic residue on the rim

WALL THICKNESS (IN MM): rim, $5.8 \mathrm{~mm}$

INTERIOR SURFACE TREATMENT: smoothed

EXTERIOR SURFACE TREATMENT:

burnished

HEIGHT (IN CM): 8.0

ORIFICE DIAMETER (IN CM): 17.0

DIAMETER AT BOTTOM OF RIM OR NECK

(IN CM): 16.5

BASE DIAMETER (IN CM) AND SHAPE OF

BASE: 5.8; circular and flat

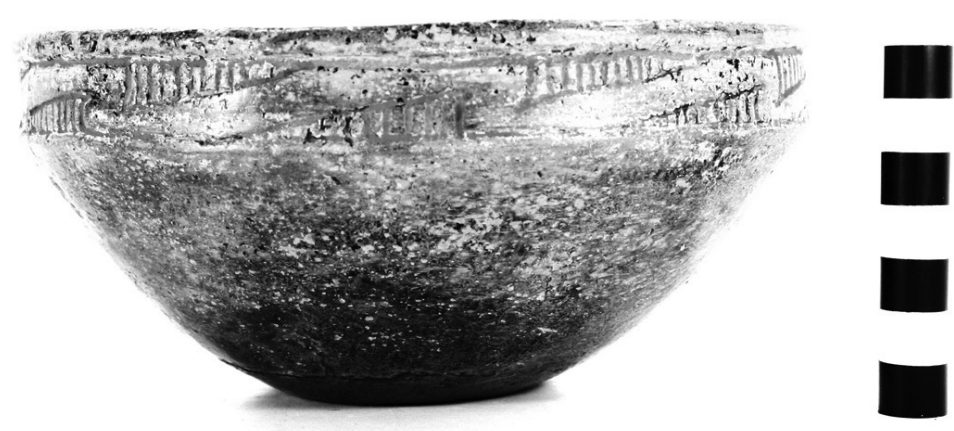

Figure 9. Ripley Engraved, var. unspecified carinated bowl.

ESTIMATED VOLUME (IN LITERS): 0.8

DECORATION (INCLUDING MOTIF AND ELEMENTS WHEN APPARENT): The rim has a continuous negative slanting scroll motif outlined by seven sets of upper and lower scroll fill zones. These fill zones are filled with a series of short vertical engraved lines (Figure 9).

PIGMENT USE AND LOCATION ON VESSEL: red in engraved lines

TYPE AND VARIETY (IF KNOWN): Ripley Engraved, var. unspecified 
SITE NAME OR SITE NUMBER: Arms Creek (Marion County)

VESSEL NO.: 4-18-85

VESSEL FORM: Carinated bowl

NON-PLASTICS AND PASTE: grog

RIM AND LIP FORM: Direct rim and rounded, exterior folded lip

CORE COLOR: F (fired in a reducing environment and cooled in the open air)

INTERIOR SURFACE COLOR: yellowish-brown

EXTERIOR SURFACE COLOR: yellowish-brown; fire clouds on the body and base

WALL THICKNESS (IN MM): $\operatorname{rim}, 6.7 \mathrm{~mm}$

INTERIOR SURFACE TREATMENT:

smoothed

EXTERIOR SURFACE TREATMENT:

burnished

HEIGHT (IN CM): 8.8

ORIFICE DIAMETER (IN CM): 16.5

DIAMETER AT BOTTOM OF RIM

OR NECK (IN CM): 16.3

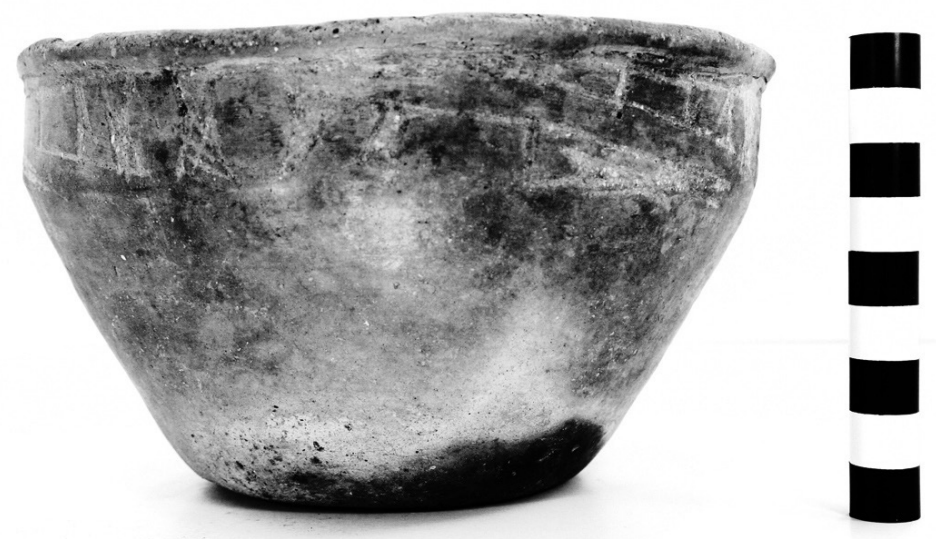

Figure 10. Ripley Engraved, var. unspecified carinated bowl.

BASE DIAMETER (IN CM) AND SHAPE OF BASE: 8.5; circular and flat

ESTIMATED VOLUME (IN LITERS): 0.87

DECORATION (INCLUDING MOTIF AND ELEMENTS WHEN APPARENT): The rim panel has an engraved slanting scroll repeated four times around the vessel. The scrolls are divided by hatched brackets. The upper and lower scroll fill zones have excised triangles and vertical lines as well as excised columns with triangular appendages (Figure 10).

PIGMENT USE AND LOCATION ON VESSEL: none

TYPE AND VARIETY (IF KNOWN): Ripley Engraved, var. unspecified 
SITE NAME OR SITE NUMBER: Arms Creek (Upshur County)

VESSEL NO.: 3-16-85

VESSEL FORM: Carinated bowl

NON-PLASTICS AND PASTE: bone

RIM AND LIP FORM: Direct rim and rounded, exterior folded lip

CORE COLOR: $\mathrm{G}$ (fired in a reducing environment and cooled in the open air)

INTERIOR SURFACE COLOR: dark grayish-brown; fire clouds on the body and base

EXTERIOR SURFACE COLOR: yellowish-brown; fire clouds on the body and base

WALL THICKNESS (IN MM): rim, $6.1 \mathrm{~mm}$

INTERIOR SURFACE TREATMENT: smoothed

EXTERIOR SURFACE TREATMENT:

burnished

HEIGHT (IN CM): 11.5

ORIFICE DIAMETER (IN CM): 24.4

DIAMETER AT BOTTOM OF RIM OR

NECK (IN CM): 24.1

BASE DIAMETER (IN CM) AND SHAPE

OF BASE: 8.0 ; circular and flat

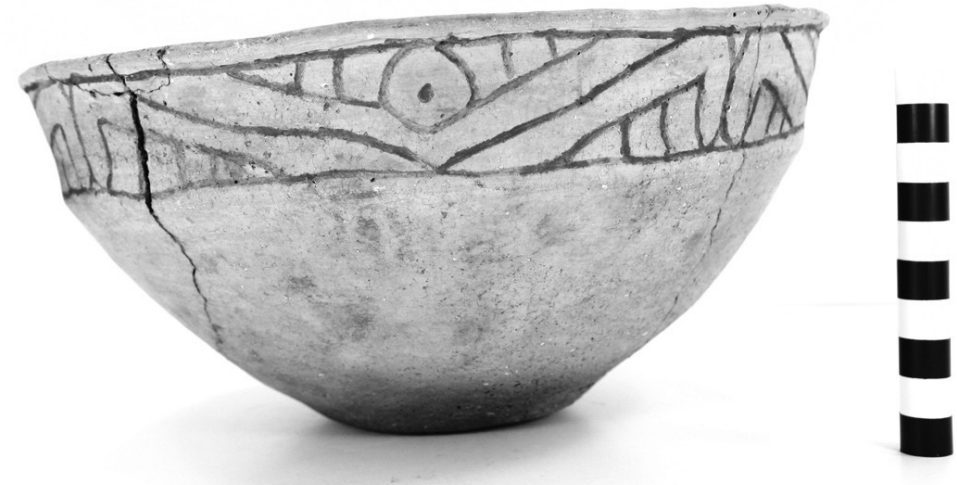

Figure 11. cf. Ripley Engraved, var. Williams carinated bowl.

ESTIMATED VOLUME (IN LITERS): 1.7

DECORATION (INCLUDING MOTIF AND ELEMENTS WHEN APPARENT): The rim panel has four sets of engraved nested triangles divided by opposed sets of curvilinear engraved lines. Each nested triangle has a central circle with a small excised dot; the circle is surrounded by a series of vertical to curvilinear engraved lines. Opposite each nested triangle motif are triangular scroll fill zones with vertical to curvilinear engraved lines (Figure 11).

PIGMENT USE AND LOCATION ON VESSEL: red pigment in the engraved lines

TYPE AND VARIETY (IF KNOWN): cf. Ripley Engraved, var. Williams 
SITE NAME OR SITE NUMBER: Arms Creek

VESSEL NO.: 5-10-85

VESSEL FORM: Carinated bowl

NON-PLASTICS AND PASTE: grog

RIM AND LIP FORM: Direct rim and rounded lip

CORE COLOR: B (fired and cooled in a reducing environment)

INTERIOR SURFACE COLOR: grayish-brown

EXTERIOR SURFACE COLOR: grayish-

brown; fire clouds on the rim, body, and base

WALL THICKNESS (IN MM): rim, $8.6 \mathrm{~mm}$

INTERIOR SURFACE TREATMENT: smoothed

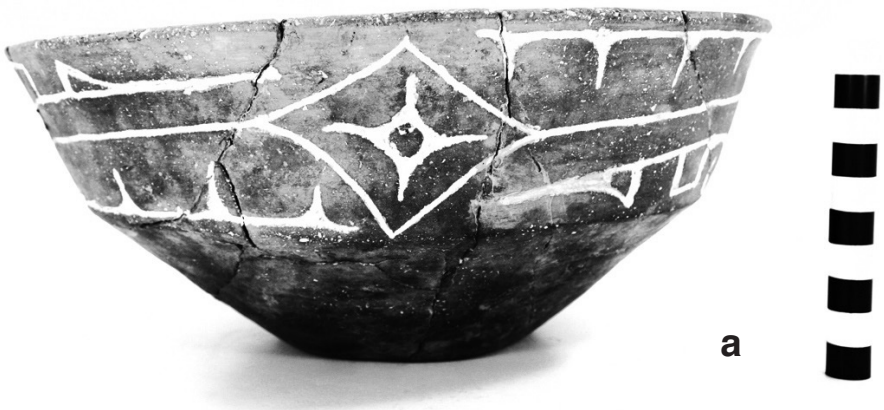

EXTERIOR SURFACE TREATMENT:

burnished

HEIGHT (IN CM): 11.5

ORIFICE DIAMETER (IN CM): 25.2

DIAMETER AT BOTTOM OF RIM OR NECK

(IN CM): 22.0

BASE DIAMETER (IN CM) AND SHAPE

OF BASE: 8.7; circular and flat

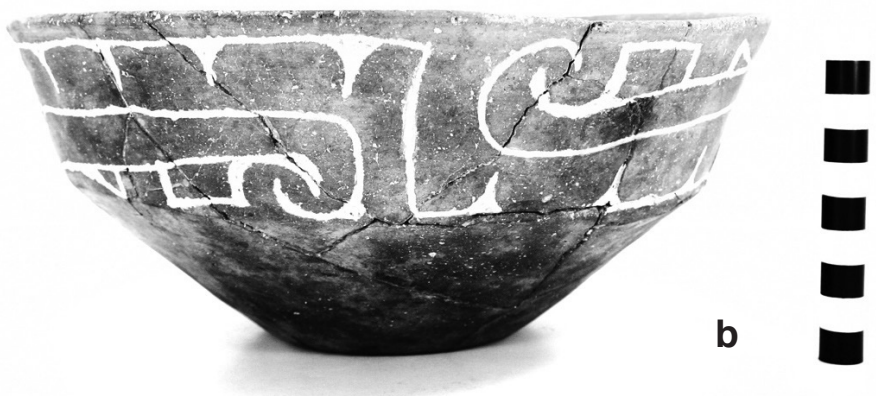

Figure 12. cf. Ripley Engraved, var. McKinney carinated bowl: a, central triangle element; b, hooked arm

ESTIMATED VOLUME (IN LITERS): 1.7 elements on scroll motif.

DECORATION (INCLUDING MOTIF AND ELEMENTS WHEN APPARENT): The rim panel has an engraved horizontal scroll motif with central engraved triangle elements (Figure 12a); the scrolls end in hooked arm elements (Figure 12b). The central triangle elements have within them small negative ovals with excised rays. Above and below the horizontal scrolls are a series of excised pendant triangles.

PIGMENT USE AND LOCATION ON VESSEL: white in the engraved lines

TYPE AND VARIETY (IF KNOWN): cf. Ripley Engraved, var. McKinney 
SITE NAME OR SITE NUMBER: Arms Creek

VESSEL NO.: 5-28-85

VESSEL FORM: Carinated bowl

NON-PLASTICS AND PASTE: grog

RIM AND LIP FORM: Direct rim and a rounded, exterior folded lip

CORE COLOR: F (fired in a reducing environment and cooled in the open air)

INTERIOR SURFACE COLOR: light brown; fire clouds on the rim, body, and base

EXTERIOR SURFACE COLOR: light brown; fire clouds on the rim, body, and base

WALL THICKNESS (IN MM): rim, $5.7 \mathrm{~mm}$

INTERIOR SURFACE TREATMENT: smoothed

EXTERIOR SURFACE TREATMENT: smoothed

HEIGHT (IN CM): 7.4

ORIFICE DIAMETER (IN CM): 13.7

DIAMETER AT BOTTOM OF RIM OR NECK (IN CM): 14.1

BASE DIAMETER (IN CM) AND SHAPE OF

BASE: 3.4; circular and rounded

ESTIMATED VOLUME (IN LITERS): 0.6

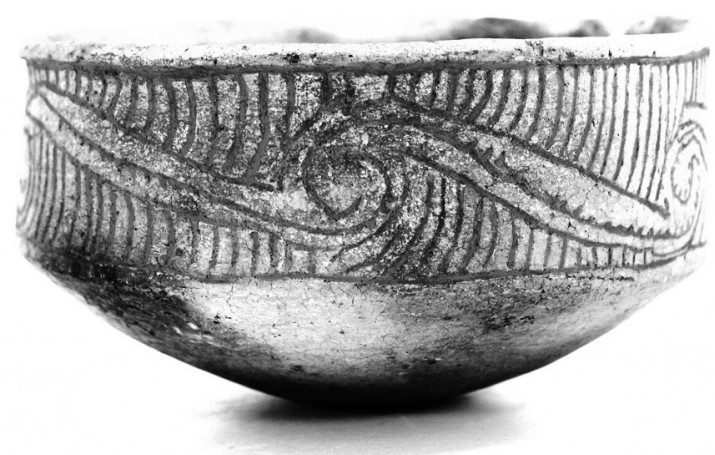

Figure 13. Taylor Engraved carinated bowl.

DECORATION (INCLUDING MOTIF AND ELEMENTS WHEN APPARENT): The rim panel has an engraved meandering scroll that is repeated six times around the vessel; the scrolls end in a hooked arm element. The central scroll line has small excised pendant triangles on it. The upper and lower scroll fill zones are filled with a series of vertical engraved lines (Figure 13).

PIGMENT USE AND LOCATION ON VESSEL: red pigment in the engraved lines

TYPE AND VARIETY (IF KNOWN): Taylor Engraved 
SITE NAME OR SITE NUMBER: Arms Creek

VESSEL NO.: 4-2-85

VESSEL FORM: Carinated bowl

NON-PLASTICS AND PASTE: grog

RIM AND LIP FORM: Direct rim and a rounded, exterior folded lip

CORE COLOR: F (fired in a reducing environment, but cooled in the open air)

INTERIOR SURFACE COLOR: dark yellowish-brown; fire clouds on the body and base

EXTERIOR SURFACE COLOR: dark yellowish-brown; fire clouds on the body and base

WALL THICKNESS (IN MM): rim, 5.6 mm

INTERIOR SURFACE TREATMENT:

smoothed

EXTERIOR SURFACE TREATMENT:

burnished

HEIGHT (IN CM): 12.6

ORIFICE DIAMETER (IN CM): 24.0

DIAMETER AT BOTTOM OF RIM OR

NECK (IN CM): 23.8

BASE DIAMETER (IN CM) AND SHAPE

OF BASE: 7.0; circular and flat

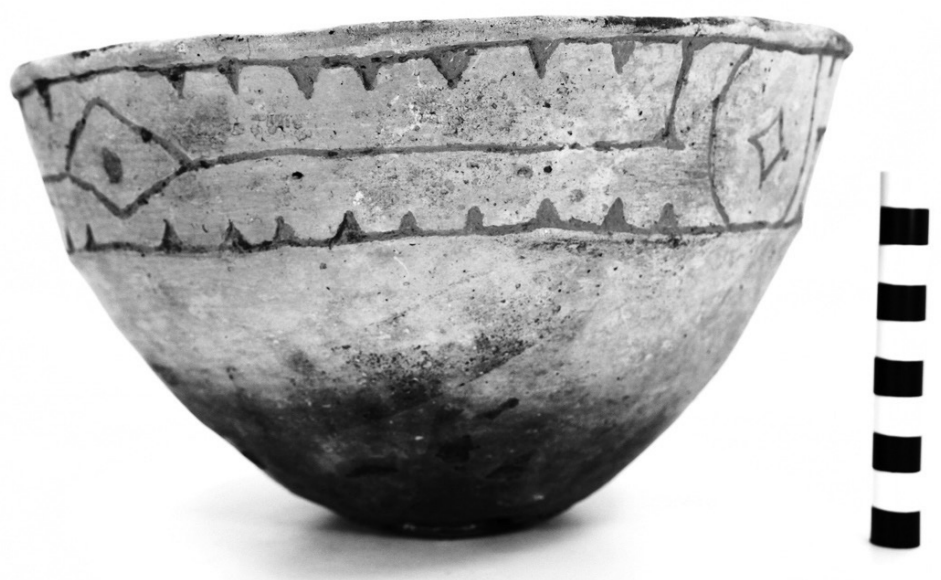

Figure 14. Ripley Engraved, var. McKinney carinated bowl.

\section{ESTIMATED VOLUME (IN LITERS): 1.8}

DECORATION (INCLUDING MOTIF AND ELEMENTS WHEN APPARENT): The rim panel has a horizontal scroll motif repeated four times with alternating circle $(n=2)$ and diamond $(n=2)$ central elements. The central circles have small negative ovals within excised diamonds, while the central diamonds are marked at their centers by an excised dot (Figure 14). Above and below each horizontal scroll are a series of small excised pendant triangles.

PIGMENT USE AND LOCATION ON VESSEL: red pigment in the engraved lines TYPE AND VARIETY (IF KNOWN): Ripley Engraved, var. McKinney 
SITE NAME OR SITE NUMBER: Arms Creek (Upshur County)

VESSEL NO.: 3-30-85

VESSEL FORM: Conjoined carinated bowl and bottle body and base

NON-PLASTICS AND PASTE: grog and bone

RIM AND LIP FORM: Inverted rim and rounded lip

CORE COLOR: $\mathrm{G}$ (fired in a reducing environment and cooled in the open air)

INTERIOR SURFACE COLOR: dark brown; fire clouds on the rim, body, and base

EXTERIOR SURFACE COLOR: reddish-brown; fire clouds on the rim, body, and base

WALL THICKNESS (IN MM): $\operatorname{rim} 3.7 \mathrm{~mm}$

INTERIOR SURFACE TREATMENT: smoothed

EXTERIOR SURFACE TREATMENT:

smoothed

HEIGHT (IN CM): 8.0

ORIFICE DIAMETER (IN CM): 14.7

DIAMETER AT BOTTOM OF RIM OR NECK

(IN CM): 16.3

BASE DIAMETER (IN CM) AND SHAPE OF

BASE: 4.6; circular and flat

\section{ESTIMATED VOLUME (IN LITERS): 0.7}

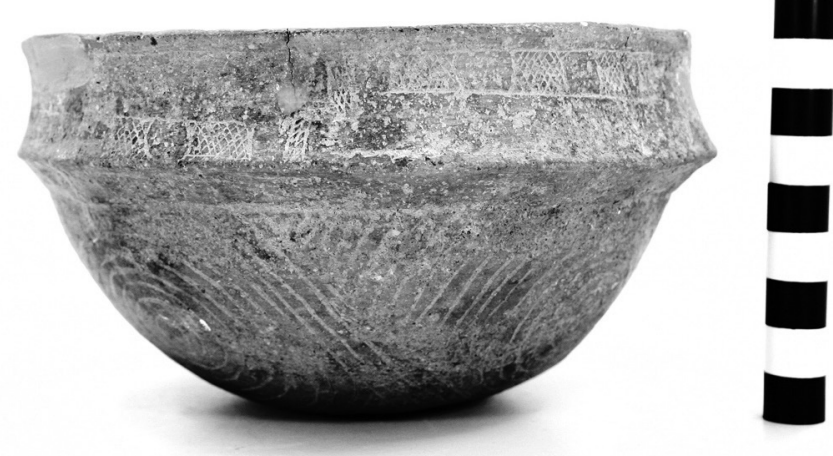

Figure 15. Conjoined cf. Simms Engraved-Taylor Engraved vessel.

DECORATION (INCLUDING MOTIF AND ELEMENTS WHEN APPARENT): The upper part of the conjoined vessel has a Simms Engraved motif consisting of three repeated sets of cross-hatched columns, brackets and diagonal tick marks, as well as dividers consisting of hatched and cross-hatched rectilinear elements and large hatched triangles with a single small negative circle. The lower part of the conjoined vessel has three sets of engraved scrolls and spirals that end in a hooked arm element (Figure 15). These scrolls and spirals are divided by sets of three diagonal engraved lines that extend from the carination to the vessel base.

PIGMENT USE AND LOCATION ON VESSEL: white in the engraved lines TYPE AND VARIETY (IF KNOWN): cf. Simms Engraved-Taylor Engraved 
SITE NAME OR SITE NUMBER: Arms Creek (Upshur County)

VESSEL NO.: 4-18-85

VESSEL FORM: Carinated bowl

NON-PLASTICS AND PASTE: grog

RIM AND LIP FORM: Inverted rim and a rounded lip

CORE COLOR: F (fired in a reducing environment and cooled in the open air)

INTERIOR SURFACE COLOR: reddish-brown; fire clouds on the body

EXTERIOR SURFACE COLOR: reddish-brown; fire clouds on the rim and body

WALL THICKNESS (IN MM): $\operatorname{rim}, 6.0 \mathrm{~mm}$

INTERIOR SURFACE TREATMENT: smoothed

EXTERIOR SURFACE TREATMENT: burnished

HEIGHT (IN CM): 10.8

ORIFICE DIAMETER (IN CM): 17.0

DIAMETER AT BOTTOM OF RIM OR NECK (IN CM): 19.4

BASE DIAMETER (IN CM) AND SHAPE OF BASE: 6.5; circular and rounded

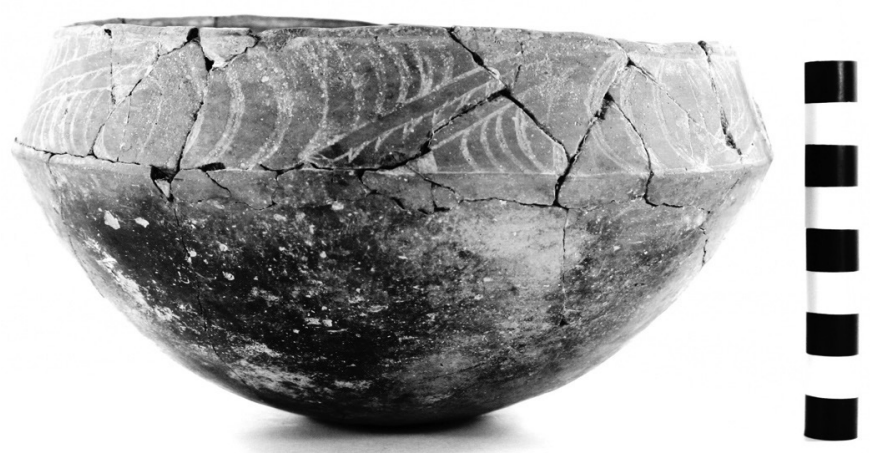

Figure 16. cf. Taylor Engraved carinated bowl.

ESTIMATED VOLUME (IN LITERS): 1.1

DECORATION (INCLUDING MOTIF AND ELEMENTS WHEN APPARENT): The rim panel has two repeating sets of engraved curvilinear scrolls, and the central scroll line has small excised tick marks. The upper and lower scroll fill zones have sets of closely-spaced curvilinear to near vertical lines. The curvilinear scrolls are divided by three sets of closely-spaced curvilinear engraved lines that extend from the rim to the vessel carination; these are repeated twice on the vessel (Figure 16).

PIGMENT USE AND LOCATION ON VESSEL: none

TYPE AND VARIETY (IF KNOWN): cf. Taylor Engraved 
SITE NAME OR SITE NUMBER: Arms Creek (Upshur County)

VESSEL NO.: 3-30-85

VESSEL FORM: Jar

NON-PLASTICS AND PASTE: grog and bone

RIM AND LIP FORM: Everted rim and rounded, exterior folded lip

CORE COLOR: $\mathrm{H}$ (fired in a reducing environment and cooled in the open air)

INTERIOR SURFACE COLOR: dark yellowishbrown; fire clouds on the rim, body, and base; considerable organic residue on the rim and body

EXTERIOR SURFACE COLOR: black

WALL THICKNESS (IN MM): rim, 6.8

INTERIOR SURFACE TREATMENT: none

EXTERIOR SURFACE TREATMENT: smoothed

HEIGHT (IN CM): 26.6

ORIFICE DIAMETER (IN CM): 28.7

DIAMETER AT BOTTOM OF RIM OR NECK (IN CM): 24.6

BASE DIAMETER (IN CM) AND SHAPE OF

BASE: 8.4; circular and flat

ESTIMATED VOLUME (IN LITERS): 9.9

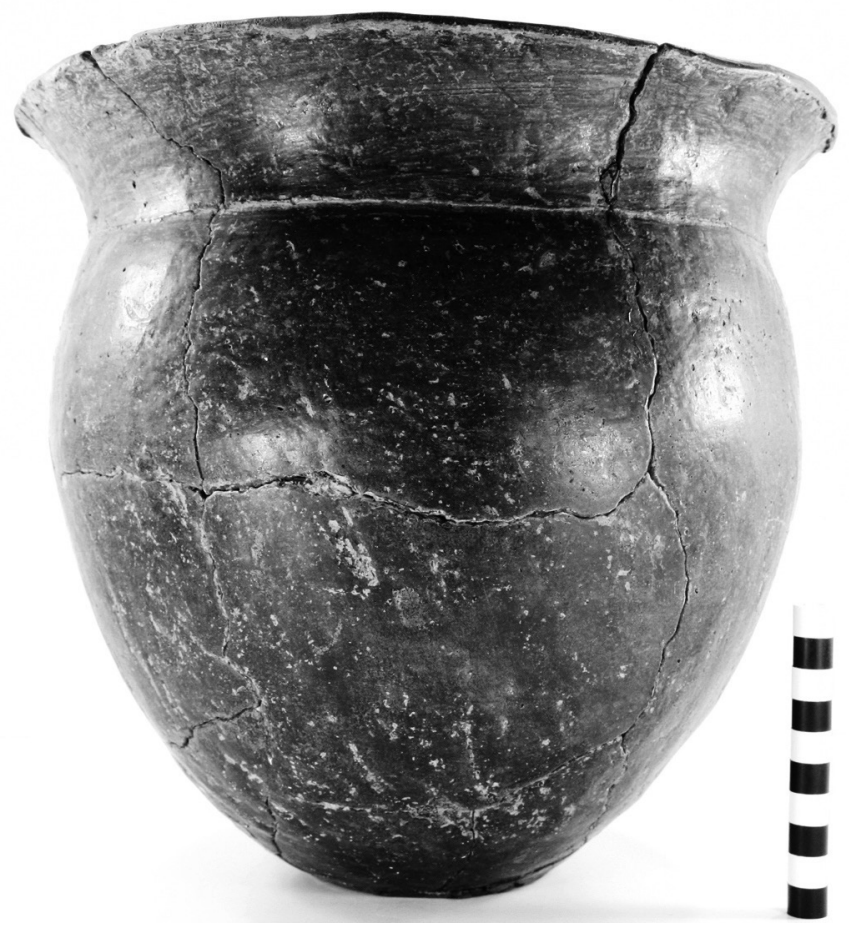

Figure 17. Large plain jar.

DECORATION (INCLUDING MOTIF AND ELEMENTS WHEN APPARENT): Plain (Figure 17) PIGMENT USE AND LOCATION ON VESSEL: none

TYPE AND VARIETY (IF KNOWN): Unidentified plain ware 
SITE NAME OR SITE NUMBER: M. C. Site (Southall, 41UR3)

VESSEL NO.: 5-29-85

VESSEL FORM: Carinated bowl

NON-PLASTICS AND PASTE: grog

RIM AND LIP FORM: Inverted rim and a rounded, exterior folded lip

CORE COLOR: F (fired in a reducing environment and cooled in the open air)

INTERIOR SURFACE COLOR: dark brown; fire clouds on the body

EXTERIOR SURFACE COLOR: brown; fire clouds on the rim, body, and base

WALL THICKNESS (IN MM): $\operatorname{rim}, 6.7 \mathrm{~mm}$

INTERIOR SURFACE TREATMENT: smoothed

EXTERIOR SURFACE TREATMENT:

burnished

HEIGHT (IN CM): 10.6

ORIFICE DIAMETER (IN CM): 21.9

DIAMETER AT BOTTOM OF RIM OR

NECK (IN CM): 24.2

BASE DIAMETER (IN CM) AND SHAPE OF

BASE: 8.8; circular and flat

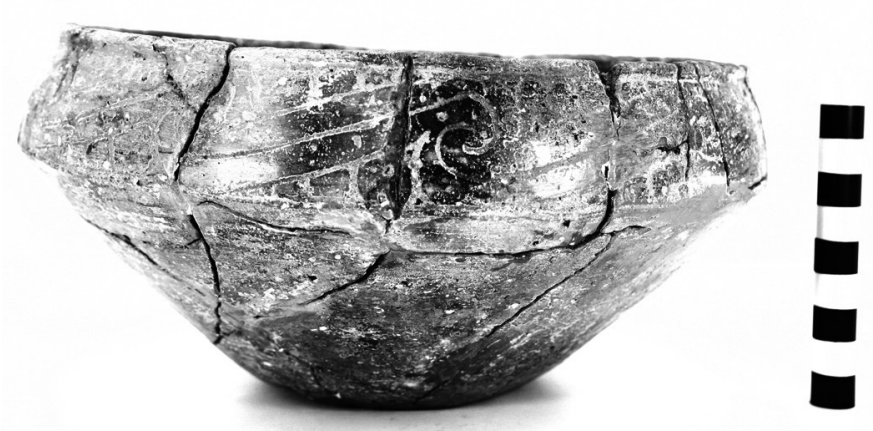

Figure 18. Taylor Engraved carinated bowl from the Southall site (41UR3).

ESTIMATED VOLUME (IN LITERS): 1.4

DECORATION (INCLUDING MOTIF AND ELEMENTS WHEN APPARENT): The rim panel has an engraved slanting scroll motif that is repeated 11 times around the vessel; the scrolls end in hooked arm elements. The upper and lower scroll fill zones are filled with vertical engraved lines (Figure 18).

PIGMENT USE AND LOCATION ON VESSEL: none

TYPE AND VARIETY (IF KNOWN): Taylor Engraved 
SITE NAME OR SITE NUMBER: M. C. Site (Southall, 41UR3)

VESSEL NO.: 5-29-85

VESSEL FORM: Carinated bowl

NON-PLASTICS AND PASTE: grog and bone

RIM AND LIP FORM: Direct rim and rounded, exterior folded lip

CORE COLOR: F (fired in a reducing environment and cooled in the open air)

INTERIOR SURFACE COLOR: brown

EXTERIOR SURFACE COLOR: brown; fire clouds on the body and base

WALL THICKNESS (IN MM): rim,

$6.4 \mathrm{~mm}$

INTERIOR SURFACE TREATMENT:

smoothed on the rim

EXTERIOR SURFACE TREATMENT:

burnished

HEIGHT (IN CM): 13.0

ORIFICE DIAMETER (IN CM): 27.0

DIAMETER AT BOTTOM OF RIM

OR NECK (IN CM): 25.0

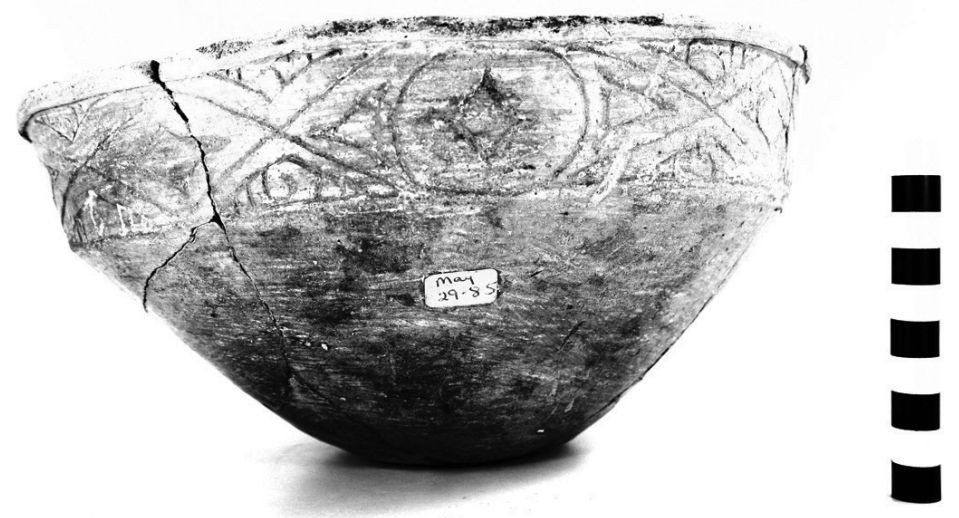

Figure 19. Ripley Engraved, var. unspecified carinated bowl.

BASE DIAMETER (IN CM) AND SHAPE OF BASE: 8.1; circular and flat

\section{ESTIMATED VOLUME (IN LITERS): 3.2}

DECORATION (INCLUDING MOTIF AND ELEMENTS WHEN APPARENT): The rim panel has four alternating sets of engraved central circles and central diamonds. The central circles have smaller central diamonds with excised corners, while there are smaller open diamonds within the central diamonds. There are also small engraved triangles with excised corners between the central circles and diamonds, while there are upper and lower engraved triangle elements on each side of the central diamond elements (Figure 19). These smaller triangle elements have hatched corners and a single hooked arm within them.

PIGMENT USE AND LOCATION ON VESSEL: none

TYPE AND VARIETY (IF KNOWN): Ripley Engraved, var. unspecified 
SITE NAME OR SITE NUMBER: M. C. Site (Southall, 41UR3)

VESSEL NO.: 5-11-85

VESSEL FORM: Carinated bowl

NON-PLASTICS AND PASTE: grog

RIM AND LIP FORM: Direct rim and rounded, exterior folded lip

CORE COLOR: $\mathrm{H}$ (fired in a reducing environment and cooled in the open air)

INTERIOR SURFACE COLOR: brown; fire clouds on the rim, body, and base

EXTERIOR SURFACE COLOR: grayish-brown; fire clouds on the rim and body; thick organic residue on the rim and body (greatly obscuring the engraved design)

WALL THICKNESS (IN MM): $\operatorname{rim}, 8.3 \mathrm{~mm}$

INTERIOR SURFACE TREATMENT: smoothed

EXTERIOR SURFACE TREATMENT: burnished

HEIGHT (IN CM): 14.5

ORIFICE DIAMETER (IN CM): 26.2

DIAMETER AT BOTTOM OF RIM OR NECK (IN CM): 25.5

BASE DIAMETER (IN CM) AND

SHAPE OF BASE: 9.0; circular and flat

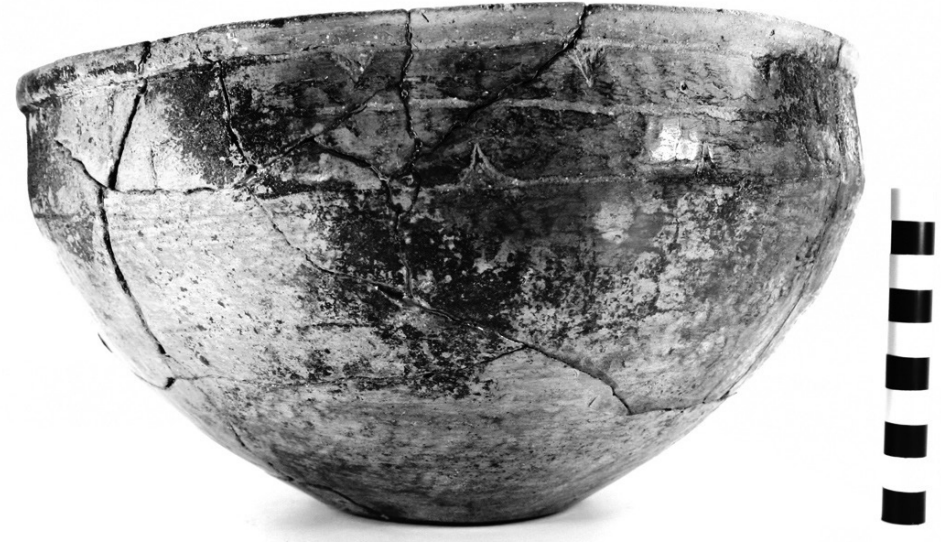

Figure 20. Ripley Engraved, var. unspecified carinated bowl.

ESTIMATED VOLUME (IN LITERS): 3.4

DECORATION (INCLUDING MOTIF AND ELEMENTS WHEN APPARENT): The rim panel has an engraved horizontal scroll repeated four times around the vessel; the scrolls end in upper and lower excised columns. The scrolls are divided by excised vertical lines that extend from the rim to the carination. Above and below each horizontal scroll are a series of small excised pendant triangles (Figure 20).

PIGMENT USE AND LOCATION ON VESSEL: none

TYPE AND VARIETY (IF KNOWN): Ripley Engraved, var. unspecified 
SITE NAME OR SITE NUMBER: M. C. Site (Southall, 41UR3)

VESSEL NO.: 8-84

VESSEL FORM: Carinated bowl

NON-PLASTICS AND PASTE: grog

RIM AND LIP FORM: Direct rim and rounded, exterior folded lip

CORE COLOR: F (fired in a reducing environment and cooled in the open air)

INTERIOR SURFACE COLOR: dark yellowish-brown; fire clouds on the rim, body, and base

EXTERIOR SURFACE COLOR: dark yellowish-brown; fire clouds on the body and base

WALL THICKNESS (IN MM): rim, $5.7 \mathrm{~mm}$

INTERIOR SURFACE TREATMENT:

smoothed

EXTERIOR SURFACE TREATMENT:

burnished

HEIGHT (IN CM): 6.5

ORIFICE DIAMETER (IN CM): 15.6

DIAMETER AT BOTTOM OF RIM OR

NECK (IN CM): 15.3

BASE DIAMETER (IN CM) AND SHAPE

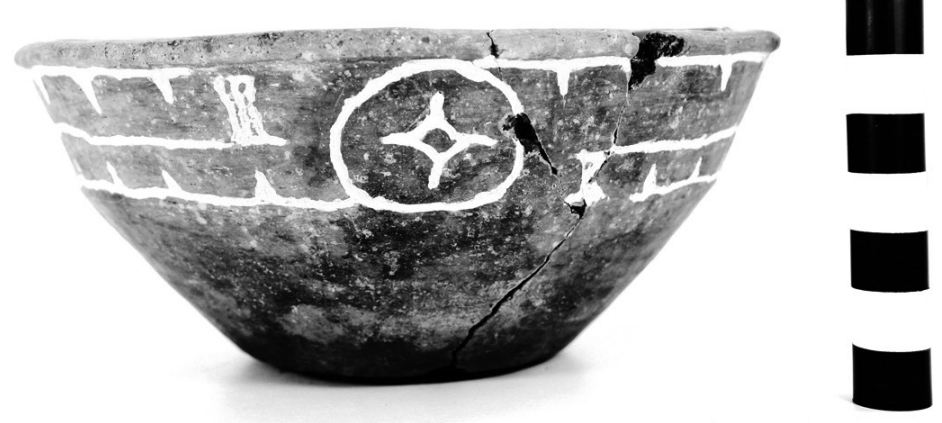

OF BASE: 6.8; circular and flat

ESTIMATED VOLUME (IN LITERS): 0.6

DECORATION (INCLUDING MOTIF AND ELEMENTS WHEN APPARENT): The rim panel has two alternating engraved central elements (circles and diamonds) in horizontal scrolls that end in excised brackets. The central diamonds have a smaller central diamonds within them, while the central circle elements have negative circles with excised rays. Above and below the horizontal scrolls are a series of excised pendant triangles (Figure 21).

PIGMENT USE AND LOCATION ON VESSEL: white pigment in engraved lines; a mass of red clay pigment remains on the inside of the vessel.

TYPE AND VARIETY (IF KNOWN): Ripley Engraved, var. McKinney 
Within the vessel is a single quartzite Maud arrow point. This point is likely an associated funerary offering.

SITE NAME OR SITE NUMBER: M. C. Site (Southall, 41UR3)

VESSEL NO.: 5-29-85

VESSEL FORM: Carinated bowl

NON-PLASTICS AND PASTE: grog

RIM AND LIP FORM: Inverted rim with a rounded, exterior folded lip

CORE COLOR: F (fired in a reducing environment and cooled in the open air)

INTERIOR SURFACE COLOR: reddish-brown; fire clouds on the body and base

EXTERIOR SURFACE COLOR: brown; fire clouds on the rim, body, and base

WALL THICKNESS (IN MM): rim, $6.1 \mathrm{~mm}$

INTERIOR SURFACE TREATMENT: smoothed

EXTERIOR SURFACE TREATMENT:

burnished

HEIGHT (IN CM): 13.2

ORIFICE DIAMETER (IN CM): 23.6

DIAMETER AT BOTTOM OF RIM

OR NECK (IN CM): 25.5

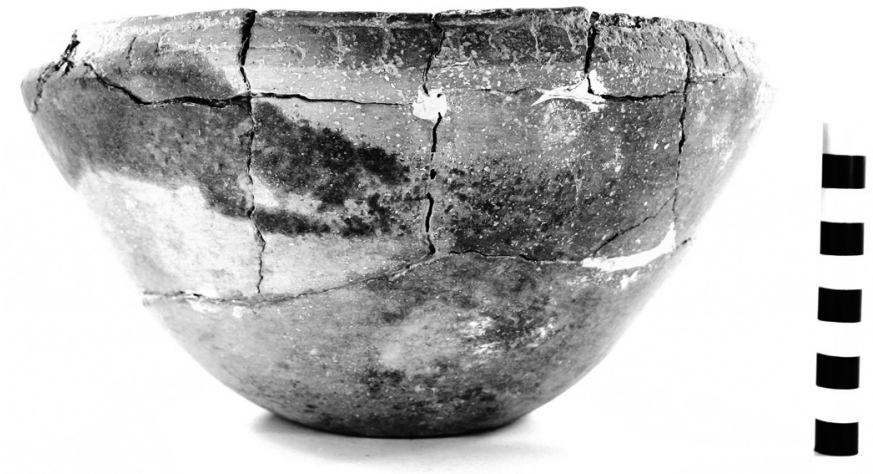

Figure 22. Simms Engraved carinated bowl.

BASE DIAMETER (IN CM) AND SHAPE OF BASE: 8.5; circular and flat

ESTIMATED VOLUME (IN LITERS): 2.8

DECORATION (INCLUDING MOTIF AND ELEMENTS WHEN APPARENT): The rim panel has an engraved horizontal scroll motif repeated 10 times around the vessel. On either side of the scrolls are one or two curvilinear engraved lines. The scroll motifs are divided by excised brackets (Figure 22).

PIGMENT USE AND LOCATION ON VESSEL: white pigment in engraved lines

TYPE AND VARIETY (IF KNOWN): Simms Engraved 
SITE NAME OR SITE NUMBER: Pine Bluff (Upshur County)

VESSEL NO.: 6-85

VESSEL FORM: Four-cornered bottle with a long neck (Figure 23)

NON-PLASTICS AND PASTE: bone and hematite

RIM AND LIP FORM: Direct rim and a rounded lip

CORE COLOR: $\mathrm{F}$ (fired in a reducing

environment and cooled in the open air)

INTERIOR SURFACE COLOR: reddish-brown

EXTERIOR SURFACE COLOR: reddish-brown; fire clouds on the base

WALL THICKNESS (IN MM): rim, 6.4 mm

INTERIOR SURFACE TREATMENT: none

EXTERIOR SURFACE TREATMENT: none

HEIGHT (IN CM): 21.6

ORIFICE DIAMETER (IN CM): 3.5

DIAMETER AT BOTTOM OF RIM OR NECK

(IN CM): 4.9; maximum body width is $12.5 \mathrm{~cm}$

BASE DIAMETER (IN CM) AND SHAPE OF

BASE: 7.0; circular and flat

ESTIMATED VOLUME (IN LITERS): 0.6

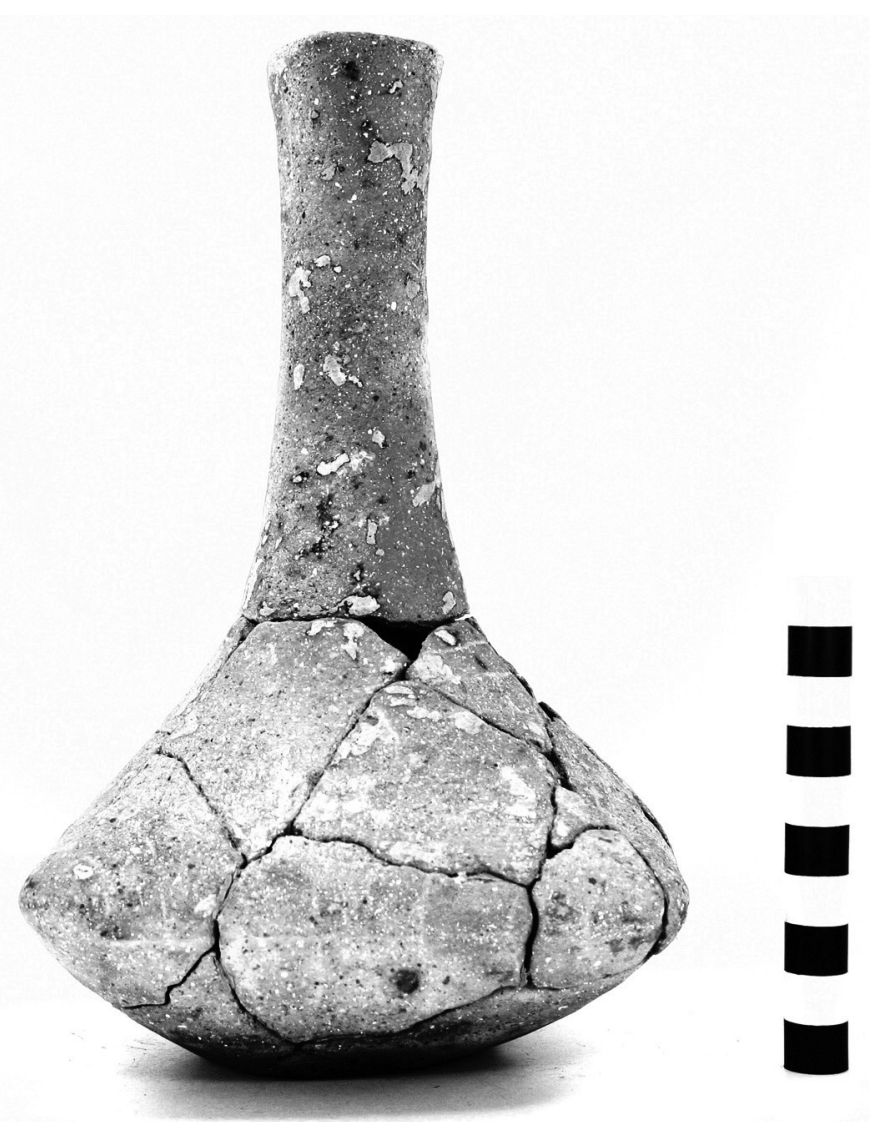

Figure 23. Unidentified four-cornered engraved bottle.

DECORATION (INCLUDING MOTIF AND ELEMENTS WHEN APPARENT): There are two horizontal engraved lines below the bottle neck and a single horizontal engraved line encircling the vessel base (Figure 23). The vessel is badly eroded.

PIGMENT USE AND LOCATION ON VESSEL: none

TYPE AND VARIETY (IF KNOWN): Unidentified fine ware, cf. Hickory Engraved 
SITE NAME OR SITE NUMBER: Unknown, likely Upshur County

VESSEL NO.: none

VESSEL FORM: Carinated bowl

NON-PLASTICS AND PASTE: grog

RIM AND LIP FORM: Direct rim and rounded, exterior folded lip

CORE COLOR: F (fired in a reducing environment and cooled in the open air)

INTERIOR SURFACE COLOR: reddish-brown; fire clouds on the rim, body, and base

EXTERIOR SURFACE COLOR: reddish-brown; fire clouds on the rim, body, and base

WALL THICKNESS (IN MM): rim, $5.1 \mathrm{~mm}$

INTERIOR SURFACE TREATMENT: smoothed

EXTERIOR SURFACE TREATMENT: burnished

HEIGHT (IN CM): 5.9

ORIFICE DIAMETER (IN CM): 11.5

DIAMETER AT BOTTOM OF RIM OR NECK

(IN CM): 11.4

BASE DIAMETER (IN CM) AND SHAPE OF

BASE: 6.1; circular and flat

ESTIMATED VOLUME (IN LITERS): 0.4

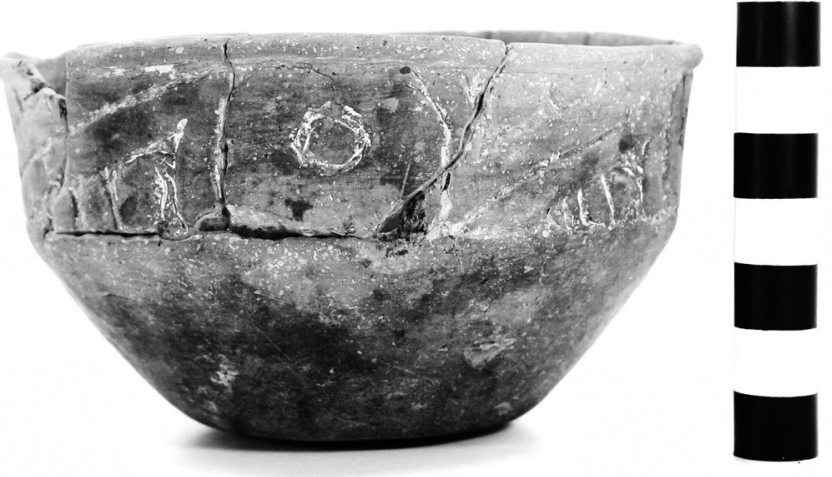

Figure 24. Ripley Engraved, var. Galt carinated bowl.

DECORATION (INCLUDING MOTIF AND ELEMENTS WHEN APPARENT): The rim has an engraved slanted scroll and circle motif repeated four times around the vessel. The central circle elements have small central open circles within them. The upper and lower scroll fill zones have two negative ovals formed by excised brackets and excised triangle elements (Figure 24).

PIGMENT USE AND LOCATION ON VESSEL: white pigment in engraved lines

TYPE AND VARIETY (IF KNOWN): Ripley Engraved, var. Galt 


\section{Vessels from Smith County Sites}

Ten ancestral Caddo vessels in the SCHM collections are thought to be from sites in Smith County, specifically from sites along the upper Neches River basin in the Lake Palestine area. One bottle is from 41SM294, a site known to have had many burials and vessels excavated from it by local residents and collectors; the other vessels are from unknown sites. The range of decorated ceramic vessels from the presumed Smith County sites date after ca. A.D. 1400, during the time of the Frankston phase (Perttula 2011); the plain vessels are likely from the same archaeological contexts.

SITE NAME OR SITE NUMBER: Villages Site (41SM294)

VESSEL NO.: none

VESSEL FORM: Carinated bottle

NON-PLASTICS AND PASTE: grog

RIM AND LIP FORM: Direct rim and rounded lip

CORE COLOR: $\mathrm{G}$ (fired in a reducing environment and cooled in the open air)

INTERIOR SURFACE COLOR: very dark grayish-brown

EXTERIOR SURFACE COLOR: brown

WALL THICKNESS (IN MM): neck, $7.3 \mathrm{~mm}$; body, $8.2 \mathrm{~mm}$

INTERIOR SURFACE TREATMENT: none

EXTERIOR SURFACE TREATMENT: smoothed

HEIGHT (IN CM): 27.0

ORIFICE DIAMETER (IN CM): 5.6

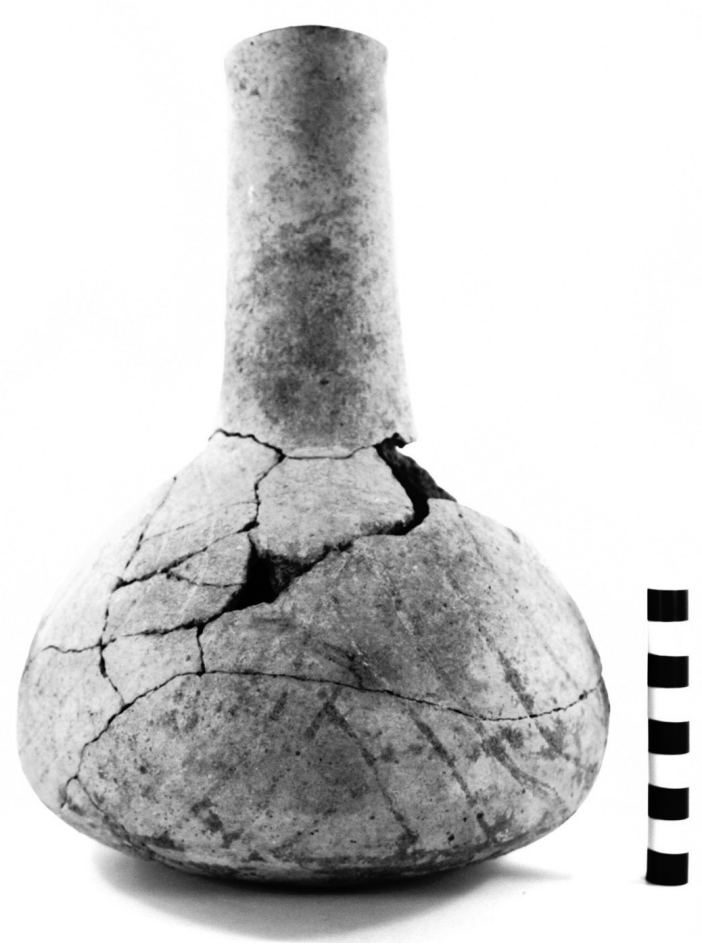

Figure 25. Unidentified engraved bottle from 41SM294.

DIAMETER AT BOTTOM OF RIM OR NECK (IN CM): 7.6; $20.0 \mathrm{~cm}$ maximum width

BASE DIAMETER (IN CM) AND SHAPE OF BASE: 8.0; circular and flat

ESTIMATED VOLUME (IN LITERS): 0.9

DECORATION (INCLUDING MOTIF AND ELEMENTS WHEN APPARENT): the vessel body has a series of engraved concentric circles repeated twice around the vessel. Between each of the series of concentric circles are attached diagonal engraved lines (Figure 25).

PIGMENT USE AND LOCATION ON VESSEL: none

TYPE AND VARIETY (IF KNOWN): Unidentified fine ware 
SITE NAME OR SITE NUMBER: Unknown Smith County

VESSEL NO.: none

VESSEL FORM: Carinated bowl

NON-PLASTICS AND PASTE: grog

RIM AND LIP FORM: Inverted rim and a rounded lip

CORE COLOR: $\mathrm{H}$ (fired in a reducing environment and cooled in the open air)

INTERIOR SURFACE COLOR: brown; fire clouds on the rim, body, and base

EXTERIOR SURFACE COLOR: very dark brown; fire clouds on the rim, body, and base

WALL THICKNESS (IN MM): rim, 5.0

INTERIOR SURFACE TREATMENT: smoothed

EXTERIOR SURFACE TREATMENT: burnished

HEIGHT (IN CM): 9.2

ORIFICE DIAMETER (IN CM): 11.6

DIAMETER AT BOTTOM OF RIM OR NECK

(IN CM): 15.4

BASE DIAMETER (IN CM) AND SHAPE OF

BASE: 6.9; circular and flat

ESTIMATED VOLUME (IN LITERS): 0.6

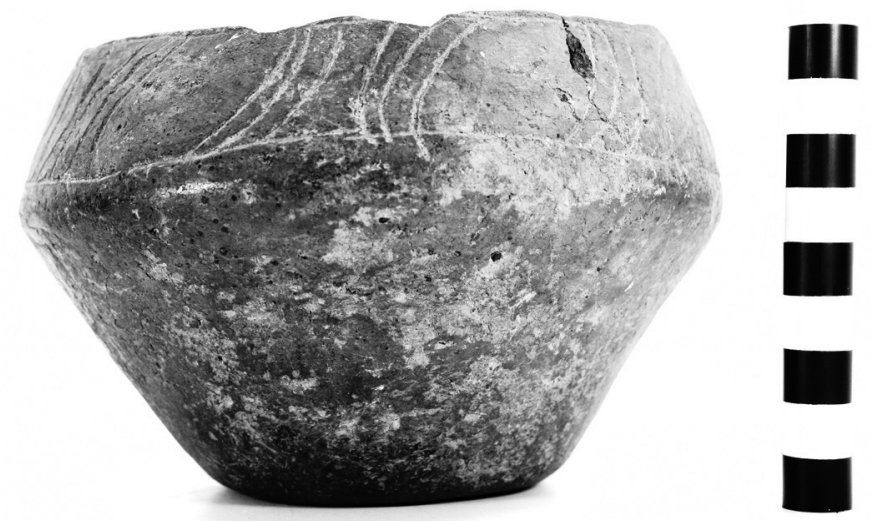

Figure 26. Poynor Engraved, var. Cook carinated bowl.

DECORATION (INCLUDING MOTIF AND ELEMENTS WHEN APPARENT): The rim has seven panels filled with ovals defined by sets of vertically-arcing engraved lines. The panels are defined by upper and lower horizontal engraved lines (Figure 26).

PIGMENT USE AND LOCATION ON VESSEL: none

TYPE AND VARIETY (IF KNOWN): Poynor Engraved, var. Cook 
SITE NAME OR SITE NUMBER: Unknown Smith County

VESSEL NO.: none

VESSEL FORM: Carinated bowl

NON-PLASTICS AND PASTE: grog

RIM AND LIP FORM: Direct rim and rounded lip

CORE COLOR: B (fired and cooled in a reducing environment)

INTERIOR SURFACE COLOR: dark grayish-brown; fire clouds on the rim

EXTERIOR SURFACE COLOR: grayish-brown; fire clouds on the rim and body

WALL THICKNESS (IN MM): rim, $4.3 \mathrm{~mm}$

INTERIOR SURFACE TREATMENT:

smoothed

EXTERIOR SURFACE TREATMENT:

burnished

HEIGHT (IN CM): 5.6+

ORIFICE DIAMETER (IN CM): 12.0

DIAMETER AT BOTTOM OF RIM OR

NECK (IN CM): 11.6

BASE DIAMETER (IN CM) AND SHAPE

OF BASE: ca. 7.5

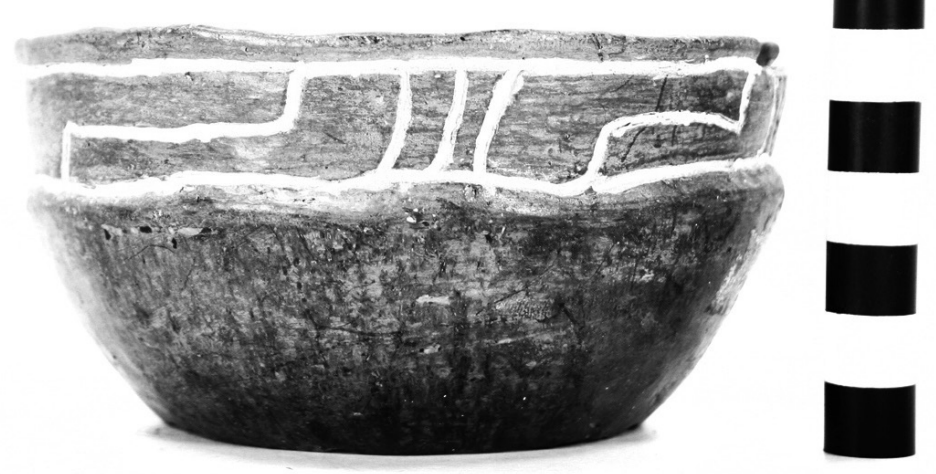

Figure 27. Poynor Engraved, var. unspecified carinated bowl.

ESTIMATED VOLUME (IN LITERS): 0.4

DECORATION (INCLUDING MOTIF AND ELEMENTS WHEN APPARENT): The rim has oval panels created by four sets of three vertical to curvilinear arcing engraved lines. Within each of the panels is a single horizontal to rectilinear scroll line (Figure 27).

PIGMENT USE AND LOCATION ON VESSEL: white clay in engraved lines

TYPE AND VARIETY (IF KNOWN): Poynor Engraved, var. unspecified 
SITE NAME OR SITE NUMBER: Unknown Smith County

VESSEL NO.: none

VESSEL FORM: Carinated bowl

NON-PLASTICS AND PASTE: grog

RIM AND LIP FORM: Inverted rim and rounded lip

CORE COLOR: F (fired in a reducing environment and cooled in the open air)

INTERIOR SURFACE COLOR: reddish-brown; fire clouds on the base and body

EXTERIOR SURFACE COLOR: reddish-brown; fire clouds on the rim, body, and base

WALL THICKNESS (IN MM): rim, $6.6 \mathrm{~mm}$

INTERIOR SURFACE TREATMENT: none

EXTERIOR SURFACE TREATMENT:

smoothed

HEIGHT (IN CM): 8.8

ORIFICE DIAMETER (IN CM): 13.4

DIAMETER AT BOTTOM OF RIM OR NECK (IN CM): 15.3

BASE DIAMETER (IN CM) AND SHAPE OF BASE: 8.7 ; circular and flat

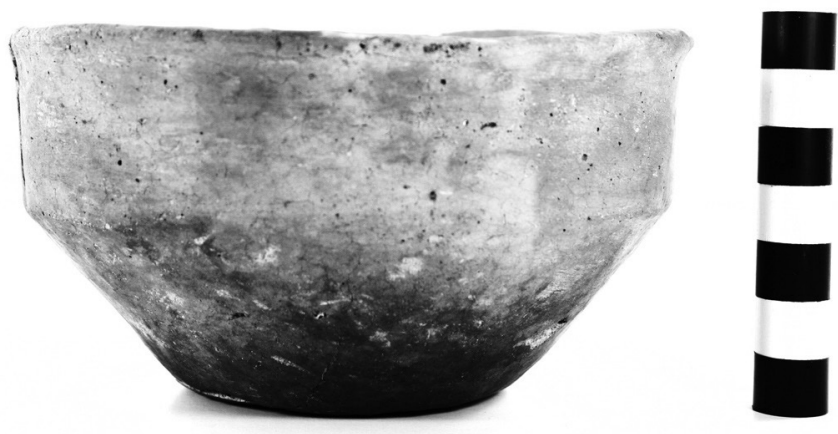

Figure 28. Plain carinated bowl.

ESTIMATED VOLUME (IN LITERS): 0.7

DECORATION (INCLUDING MOTIF AND ELEMENTS WHEN APPARENT): Plain (Figure 28)

PIGMENT USE AND LOCATION ON VESSEL: none

TYPE AND VARIETY (IF KNOWN): Unidentified plain ware 
SITE NAME OR SITE NUMBER: Unknown Smith County

VESSEL NO.: none

VESSEL FORM: Jar

NON-PLASTICS AND PASTE: grog and bone

RIM AND LIP FORM: Everted rim and rounded lip

CORE COLOR: $\mathrm{G}$ (fired in a reducing environment and cooled in the open air)

INTERIOR SURFACE COLOR: black

EXTERIOR SURFACE COLOR: brown; fire clouds on the base; organic residue on the rim and body

WALL THICKNESS (IN MM): rim, $7.2 \mathrm{~mm}$

INTERIOR SURFACE TREATMENT: smoothed

EXTERIOR SURFACE TREATMENT: none

HEIGHT (IN CM): 13.5

ORIFICE DIAMETER (IN CM): 12.8

DIAMETER AT BOTTOM OF RIM OR NECK

(IN CM): 12.2

BASE DIAMETER (IN CM) AND SHAPE OF

BASE: 9.0; circular and flat

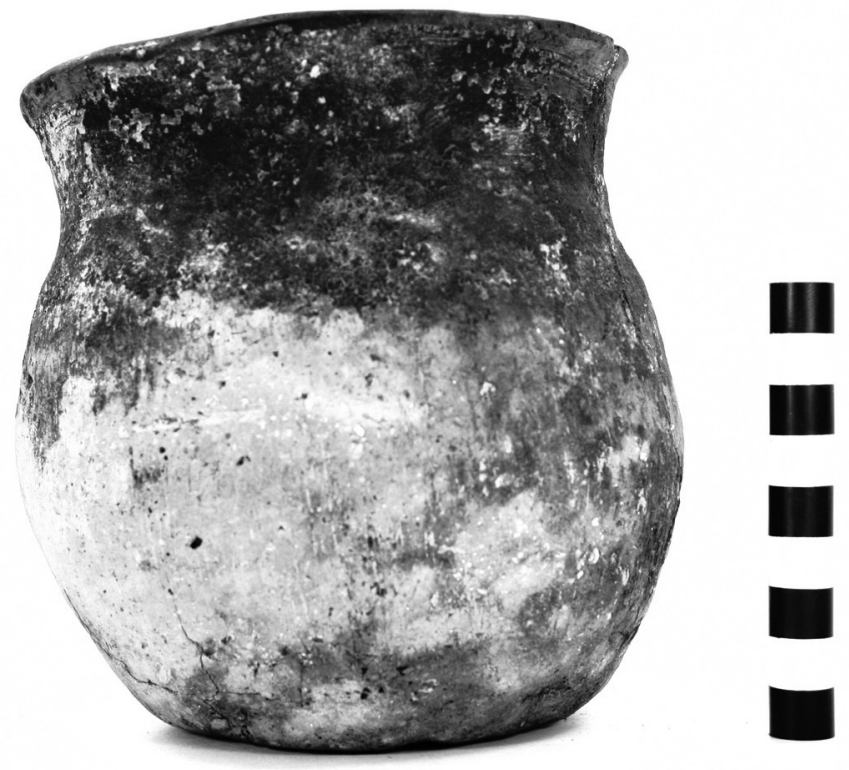

Figure 29. Bullard Brushed jar.

ESTIMATED VOLUME (IN LITERS): 1.0

DECORATION (INCLUDING MOTIF AND ELEMENTS WHEN APPARENT): The rim is decorated with horizontal brushing marks, and the vessel body has vertical brushing marks that extend from the rim-body juncture to the base (Figure 29).

PIGMENT USE AND LOCATION ON VESSEL: none

TYPE AND VARIETY (IF KNOWN): Bullard Brushed 
SITE NAME OR SITE NUMBER: Unknown Smith County

VESSEL NO.: none

VESSEL FORM: Bowl

NON-PLASTICS AND PASTE: grog

RIM AND LIP FORM: Direct rim and a rounded, interior thickened, lip (Figure 30b)

CORE COLOR: A (fired and cooled in an oxidizing environment)

INTERIOR SURFACE COLOR: dark red; fire clouds on the rim and body

EXTERIOR SURFACE COLOR: dark red; fire clouds on the rim and body

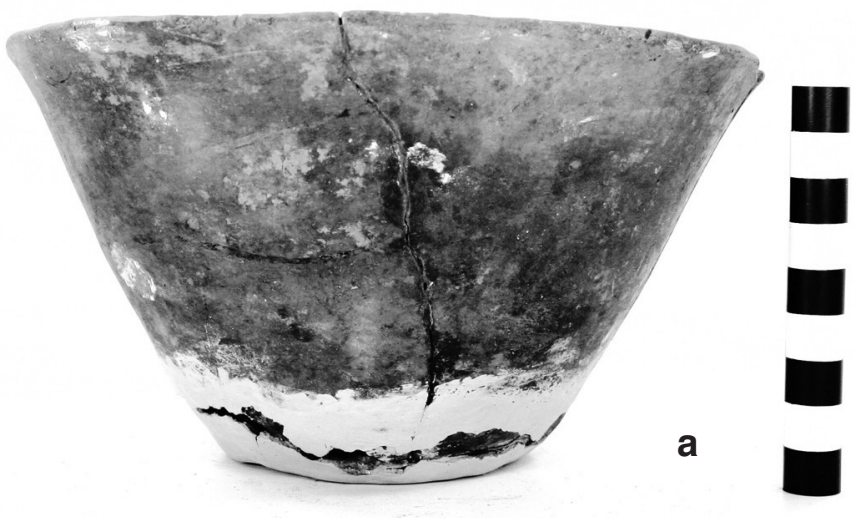

WALL THICKNESS (IN MM): rim, $5.1 \mathrm{~mm}$

INTERIOR SURFACE TREATMENT: smoothed

EXTERIOR SURFACE TREATMENT: smoothed

HEIGHT (IN CM): 10.3

ORIFICE DIAMETER (IN CM): 18.1

DIAMETER AT BOTTOM OF RIM OR NECK (IN CM): N/A

BASE DIAMETER (IN CM) AND SHAPE OF BASE: N/A

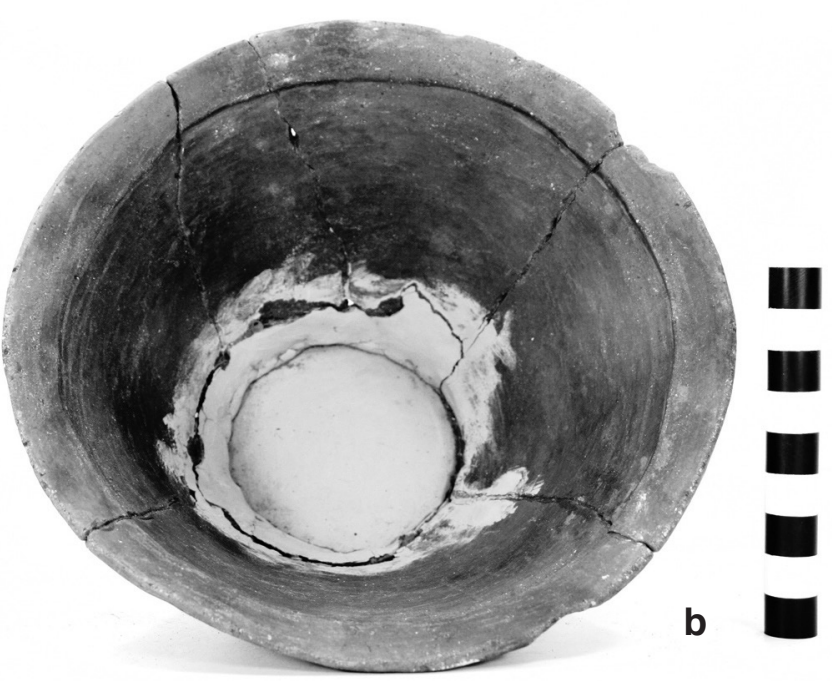

Figure 30. Plain bowl: a, side view; $b$, view of interior ESTIMATED VOLUME (IN LITERS): 0.7 thickened rim.

DECORATION (INCLUDING MOTIF AND ELEMENTS WHEN APPARENT): Plain (Figure 30a)

PIGMENT USE AND LOCATION ON VESSEL: none

TYPE AND VARIETY (IF KNOWN): Unidentified plain ware 
SITE NAME OR SITE NUMBER: Unknown Smith County

VESSEL NO.: none

VESSEL FORM: Jar

NON-PLASTICS AND PASTE: grog

RIM AND LIP FORM: Everted rim and rounded lip

CORE COLOR: F (fired in a reducing environment and cooled in the open air)

INTERIOR SURFACE COLOR: reddish-brown; fire clouds on the body

EXTERIOR SURFACE COLOR: reddish-brown; fire clouds on the rim, body, and base

WALL THICKNESS (IN MM): rim, 5.4 mm; body, $5.5 \mathrm{~mm}$

INTERIOR SURFACE TREATMENT: smoothed

EXTERIOR SURFACE TREATMENT: none

HEIGHT (IN CM): 30.5

ORIFICE DIAMETER (IN CM): 28.8

DIAMETER AT BOTTOM OF RIM OR NECK (IN CM): 23.0

BASE DIAMETER (IN CM) AND SHAPE OF

BASE: 8.0; circular and flat

ESTIMATED VOLUME (IN LITERS): 11.3

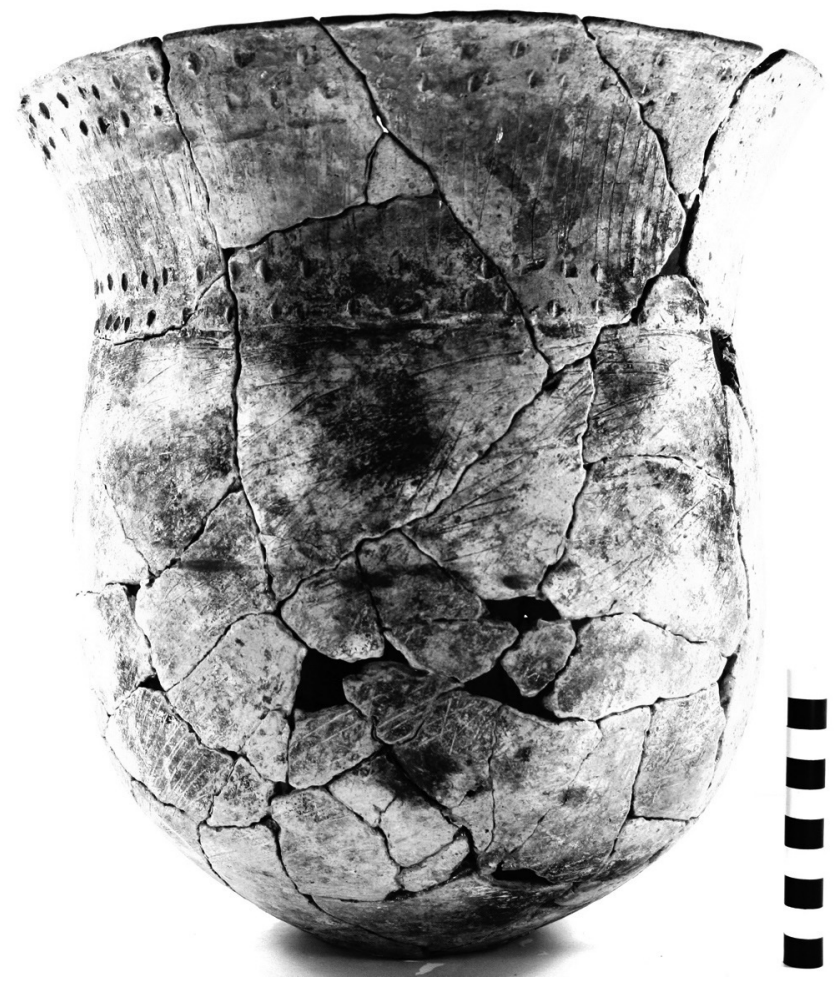

Figure 31. Large Maydelle Incised jar.

DECORATION (INCLUDING MOTIF AND ELEMENTS WHEN APPARENT): The rim has two upper and two lower rows of tool punctations, with a continuous series of vertical incised lines between the punctated rows. The vessel body is decorated with overlapping brushed marks (Figure 31).

PIGMENT USE AND LOCATION ON VESSEL: none

TYPE AND VARIETY (IF KNOWN): Maydelle Incised 
SITE NAME OR SITE NUMBER: Unknown Smith County

VESSEL NO.: none

VESSEL FORM: Carinated bowl

NON-PLASTICS AND PASTE: grog

RIM AND LIP FORM: Direct rim and rounded, exterior folded lip

CORE COLOR: A (fired and cooled in an oxidizing environment)

INTERIOR SURFACE COLOR: light reddish-brown; fire clouds on the rim and base

EXTERIOR SURFACE COLOR: reddish-brown; fire clouds on the rim, body, and base

WALL THICKNESS (IN MM): rim, $6.0 \mathrm{~mm}$

INTERIOR SURFACE TREATMENT: smoothed

EXTERIOR SURFACE TREATMENT: smoothed

HEIGHT (IN CM): 6.2

ORIFICE DIAMETER (IN CM): 12.2

DIAMETER AT BOTTOM OF RIM OR NECK (IN CM): 11.8

BASE DIAMETER (IN CM) AND SHAPE OF BASE: 6.1; circular and flat

ESTIMATED VOLUME (IN LITERS): 0.5

DECORATION (INCLUDING MOTIF AND ELEMENTS WHEN APPARENT): Plain

PIGMENT USE AND LOCATION ON VESSEL: none

TYPE AND VARIETY (IF KNOWN): Unidentified plain ware 
SITE NAME OR SITE NUMBER: Unknown Smith County

VESSEL NO.: none

VESSEL FORM: Jar with four rim peaks and two lug handles ( 25 x $17 \mathrm{~mm}$ in length and width)

NON-PLASTICS AND PASTE: grog

RIM AND LIP FORM: Everted rim and rounded lip

CORE COLOR: B (fired and cooled in a reducing environment)

INTERIOR SURFACE COLOR: black; organic residue on the rim

EXTERIOR SURFACE COLOR: black; fire clouds on the rim, body, and base

WALL THICKNESS (IN MM): rim, $4.7 \mathrm{~mm}$

INTERIOR SURFACE TREATMENT: smoothed

EXTERIOR SURFACE TREATMENT: smoothed

HEIGHT (IN CM): 23.4

ORIFICE DIAMETER (IN CM): 16.8

DIAMETER AT BOTTOM OF RIM OR NECK (IN CM): 16.3

BASE DIAMETER (IN CM) AND SHAPE OF BASE:

9.0; circular and flat

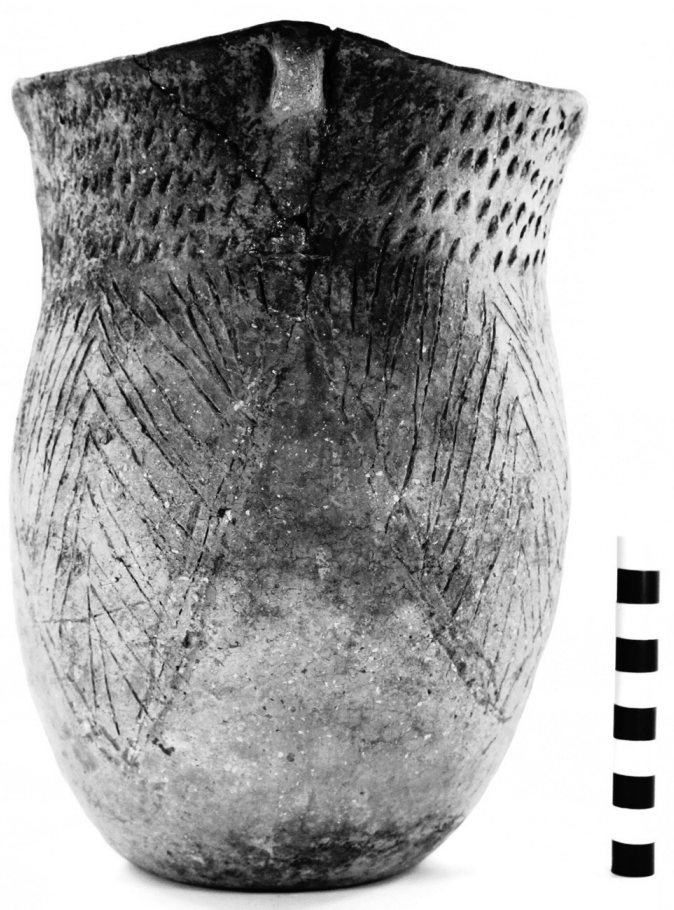

Figure 32. Punctated-appliqued-incised jar.

\section{ESTIMATED VOLUME (IN LITERS): 3.5}

DECORATION (INCLUDING MOTIF AND ELEMENTS WHEN APPARENT): The rim is decorated with five rows of tool punctations; there are also short vertical appliqued ridges on the rim below the lug handles. The vessel body has four sets of large appliqued ridge triangles pendant from the rim-body juncture. Each of these appliqued triangles are filled with sets of diagonal opposed incised lines (Figure 32).

PIGMENT USE AND LOCATION ON VESSEL: none

TYPE AND VARIETY (IF KNOWN): Unidentified utility ware 
SITE NAME OR SITE NUMBER: Unknown Smith County

VESSEL NO.: none

VESSEL FORM: Bowl

NON-PLASTICS AND PASTE: grog

RIM AND LIP FORM: Direct rim and rounded lip

CORE COLOR: B (fired and cooled in a reducing environment)

INTERIOR SURFACE COLOR: black

EXTERIOR SURFACE COLOR: dark gray; fire clouds on the rim and body

WALL THICKNESS (IN MM): rim, $5.1 \mathrm{~mm}$; body, $5.2 \mathrm{~mm}$

INTERIOR SURFACE TREATMENT: none

EXTERIOR SURFACE TREATMENT: smoothed

HEIGHT (IN CM): 12.0

ORIFICE DIAMETER (IN CM): 19.4

DIAMETER AT BOTTOM OF RIM OR NECK

(IN CM): N/A

BASE DIAMETER (IN CM) AND SHAPE OF

BASE: circular/rounded

ESTIMATED VOLUME (IN LITERS): 0.9

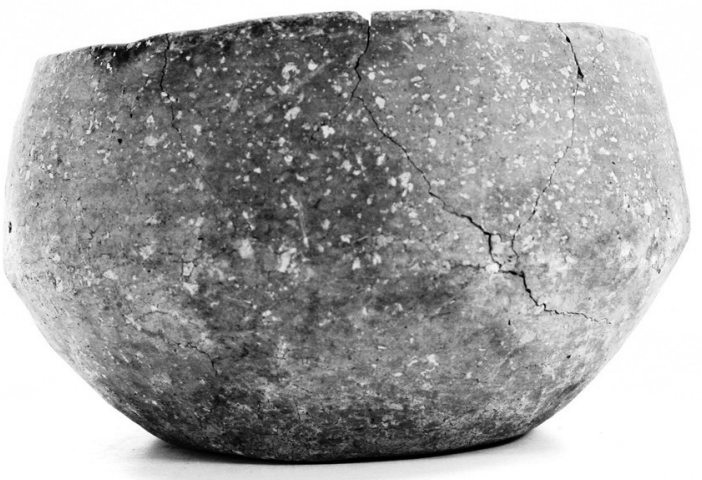

Figure 33. Plain bowl.

DECORATION (INCLUDING MOTIF AND ELEMENTS WHEN APPARENT): Plain (Figure 33)

PIGMENT USE AND LOCATION ON VESSEL: none

TYPE AND VARIETY (IF KNOWN): Unidentified plain ware 


\section{Summary and Conclusions}

The documentation of 34 ancestral Caddo ceramic vessels in the Smith County Historical Museum (SCHM) collections indicates that 23 are from Late Caddo Titus phase (ca. A.D. 1430-1680) sites in the Lake O' the Pines area (Marion and Upshur counties) of the Big Cypress Creek basin in East Texas. The stylistic character of the engraved fine wares (as well as the one triangular Maud arrow points found inside one of the vessels) suggests they were collected from ca. A.D. 1550-1680 Titus phase sites. The identified fine wares include a cf. Taylor Engraved compound bowl as well as three carinated bowls, Simms Engraved vessels ( $n=4)$, a conjoined Simms-Taylor Engraved carinated bowl, 10 Ripley bowls of several defined varieties (cf. var. Galt, cf. var. Williams, var. McKinney). Utility ware vessels from the Lake O' the Pines sites include one Harleton Appliqued jar; a very large cf. McKinney Plain jar; and a brushed-punctated-appliqued jar. Plain wares in the collection include only a single large plain jar.

The one bottle from the Pine Bluff site at Lake O' the Pines may be from a pre-A.D. 1300 Caddo occupation. It is decorated only with horizontal engraved lines on the bottle neck and bottle, and may be identified as an Early Caddo Hickory Engraved vessel (see Suhm and Jelks 1962:71 and Plate 36).

The remaining 10 vessels in the SCHM collections are from an unknown number of sites that are likely located in the upper Neches River basin in Smith County, Texas. The stylistic character of these latter vessels suggests they are from ca. A.D. 1400-1650 Frankston phase Caddo groups that lived in this part of East Texas. They include engraved fine ware bottles and carinated bowls (of the Poynor Engraved type), Bullard Brushed, Maydelle Incised, and punctated-incised-appliqued utility ware jars, and plain carinated bowls and bowls.

\section{References Cited}

Perttula, T. K.

2011 The Ceramic Artifacts from the Lang Pasture Site (41AN38) and the Place of the Site within an Upper Neches River Basin Caddo Ceramic Tradition. In Archeological Investigations at the Lang Pasture Site (41AN38) in the Upper Neches River Basin of East Texas, assembled and edited by T. K. Perttula, D. B. Kelley, and R. A. Ricklis, pp. 145-320. Archeological Studies Program Report No. 129. Texas Department of Transportation, Environmental Affairs Division, Austin.

2012 The Character of Fifteenth- to Seventeenth-Century Caddo Communities in the Big Cypress Creek Basin of Northeast Texas. In The Archaeology of the Caddo, edited by T. K. Perttula and C. P. Walker, pp. 363-410. University of Nebraska Press, Lincoln.

2013 Caddo Ceramics in East Texas. Bulletin of the Texas Archeological Society 84:181-212.

2014 The Horton Site (41CP16) on Big Cypress Creek in the East Texas Pineywoods. Journal of Northeast Texas Archaeology 43:27-43.

Perttula, T. K. and B. Nelson

2013 Two Middle Caddo Period Habitation Sites and Cemeteries in the Sabine River Basin, Gregg County, Texas. Special Publication No. 27. Friends of Northeast Texas Archaeology, Pittsburg and Austin. 
Perttula, T. K. and M. Thacker

2014 Analysis of New Artifact Collections from Archaic to Ancestral Caddo Sites in the Saline Creek Basin in Northern Smith County, Texas. Journal of Northeast Texas Archaeology 43:1-25.

Perttula, T. K., P. S. Marceaux, and B. Nelson

2012a Study of the Margaret Hinton Collection of Pottery Vessels from Northeast Texas Caddo Cemeteries. Special Publication No. 24. Friends of Northeast Texas Archaeology, Austin and Pittsburg.

Perttula, T. K., B. Nelson, and R. Z. Selden, Jr.

2013 Documentation of Cemeteries and Funerary Offerings from Sites in the Upper Neches River Basin, Anderson, Cherokee, and Smith Counties, Texas. Special Publication No. 26. Friends of Northeast Texas Archaeology, Pittsburg and Austin.

Perttula, T. K., B. Nelson, and M. Walters

2012b Caddo Archaeology at the Henry Spencer Site (41UR315) in the Little Cypress Creek Basin of East Texas. Special Publication No. 20. Friends of Northeast Texas Archaeology, Pittsburg and Austin.

Perttula, T. K., R. Z. Selden, Jr., and B. Nelson

2014 A Catalog of Selected Caddo Ceramic Vessels in the Buddy Jones Collection at the Gregg County Historical Museum. Special Publication No. 30. Friends of Northeast Texas Archaeology, Pittsburg and Austin.

Perttula, T. K., M. Walters, and B. Nelson

2009a Documentation of the Native American Ceramic Vessels from Northeast Texas, Southern Arkansas, and Eastern Oklahoma in the Boyce Smith Museum in Troup, Texas. Special Publication No. 8. Friends of Northeast Texas Archaeology, Pittsburg and Austin.

2010a Caddo Pottery Vessels and Pipes from Sites in the Big Cypress, Sulphur, Neches-Angelina, and Middle Sabine River Basins in the Turner and Johns Collections, Camp, Cass, Cherokee, Harrison, Morris, Titus, and Upshur Counties, Texas and Sabine Parish, Louisiana. Special Publication No. 10. Friends of Northeast Texas Archaeology, Pittsburg and Austin.

2010b Caddo Pottery Vessels and Pipes from the Johns Site (41CP12) in the Big Cypress Creek Basin in the Turner and Johns Collections, Camp County, Texas. Special Publication No. 11. Friends of Northeast Texas Archaeology, Austin and Pittsburg.

2012c Little Cypress Creek Basin Archaeology: Six Late Caddo Period Cemeteries in Upshur County, Texas. Special Publication No. 22. Friends of Northeast Texas Archaeology, Austin and Pittsburg.

Perttula, T. K., M. Walters, S. Marceaux, and B. Nelson

2009b Caddo Pottery Vessels and Pipes from Sites in the Middle and Upper Sabine and Upper Neches River Basins, Smith and Wood Counties, Texas. Special Publication No. 7. Friends of Northeast Texas Archaeology, Pittsburg and Austin.

Perttula, T. K., M. Walters, R. Cast, B. Gonzalez, and B. Nelson

2007 Documentation of Funerary Offerings from a Prehistoric Caddo Burial at Site 41WD244, Wood County, Texas. Caddo Nation of Oklahoma and Archeological \& Environmental Consultants, LLC, Binger and Austin. 
Perttula, T. K., M. Walters, B. Nelson, B. Gonzalez, and R. Cast, with a contribution by R. G. Franciscus 2010c Documentation of Associated and Unassociated Caddo Funerary Objects in the Stephen F. Austin State University Collections, Nacogdoches, Texas. Stephen F. Austin State University Press, Nacogdoches.

Suhm, D. A. and E. B. Jelks (editors)

1962 Handbook of Texas Archeology: Type Descriptions. Special Publication No. 1, Texas Archeological Society, and Bulletin No. 4, Texas Memorial Museum, Austin. Reprinted in 2009, Gustav's Library, Davenport, Iowa.

Thurmond, J. P.

1990 Archeology of the Cypress Creek Drainage Basin, Northeastern Texas and Northwestern Louisiana. Studies in Archeology 5. Texas Archeological Research Laboratory, The University of Texas at Austin. 